Article

\title{
Synthesis of Fluorinated 3,6-Dihydropyridines and 2-(Fluoromethyl)pyridines by Electrophilic Fluorination of 1,2-Dihydropyridines with Selectfluor ${ }^{\circledR}$
}

\author{
Nadiia V. Pikun ${ }^{1, *(\mathbb{D}}$, Arkadij Sobolev ${ }^{1}{ }^{\mathbb{D}}$, Aiva Plotniece ${ }^{1}{ }^{\mathbb{D}}$, Martins Rucins $^{1}{ }^{1}$, Brigita Vigante ${ }^{1}$, \\ Marina Petrova ${ }^{1}{ }^{(}$, Ruslan Muhamadejev $^{1}\left(\mathbb{D}\right.$, Karlis Pajuste $^{1}$ and Yuriy G. Shermolovich ${ }^{2}(\mathbb{C}$ \\ 1 Latvian Institute of Organic Synthesis, Aizkraukles Str. 21, LV-1006 Riga, Latvia; arkady@osi.lv (A.S.); \\ aiva@osi.lv (A.P.); rucins@osi.lv (M.R.); vigante@osi.lv (B.V.); marina@osi.lv (M.P.); \\ muhamadejev@osi.lv (R.M.); kpajuste@osi.lv (K.P.) \\ 2 Institute of Organic Chemistry NAS of Ukraine, Murmanska Str. 5, 02660 Kyiv, Ukraine; sherm@ioch.kiev.ua \\ * Correspondence: nadiia@osi.lv; Tel.: +371-67014928
}

Academic Editor: Mohamed Abarbri

Received: 4 June 2020; Accepted: 8 July 2020; Published: 9 July 2020

check for updates

\begin{abstract}
New fluorinated 3,6-dihydropyridines were obtained by the electrophilic fluorination of 1,2-dihydropyridines with Selectfluor ${ }^{\circledR}$. These 3-fluoro-3,6-dihydropyridines were easily converted to corresponding pyridines by the elimination of hydrogen fluoride under mild conditions. A new approach to the synthesis of methyl 2-(fluoromethyl)-5-nitro-6-arylnicotinates by the fluorination of 3-fluoro-2-methyl-5-nitro-3,6-dihydropyridines or 1,2-dihydropyridines with Selectfluor ${ }^{\circledR}$ has been developed.
\end{abstract}

Keywords: dihydropyridines; electrophilic fluorination; Selectfluor ${ }^{\circledR}$; homoallyl long-range coupling; fluorine-containing heterocycles

\section{Introduction}

The incorporation of fluorine into organic compounds has become a commonly used tool in medicinal chemistry and agrochemistry. The presence of fluorine may result in substantial changes in the biological, as well as physicochemical, properties of organic compounds. The incorporation of fluorine into a drug structure can drastically influence its physicochemical properties, such as bond strength, lipophilicity, bioavailability, conformation, electrostatic potential, dipole moment, pKa, etc. The fluorination of organic compounds also significantly affects their pharmacological properties and toxicology [1-3]. The majority of currently marketed modern drugs have heterocyclic fragments in their structures. The fluorinated heterocycles are becoming more significant in a number of disciplines, in particular, the pharmaceutical industry, materials science and agriculture [1-3].

The electrophilic fluorination of aromatic heterocycles has been less studied than the fluorination of arenes. However, a number of fluoropyrroles [4,5], furans [6], thiophenes [7], pyrrolo[2,3-d]pyrimidines [8,9], quinolines [10-12] and indoles [13-22] have been prepared either by direct fluorination or by fluorodecarboxylation using mainly Selectfluor ${ }^{\circledR}$ and $N$-fluorobenzenesulfonimide.

The chemistry of the pyridines has been extended by the development of many significant transformations, such as addition, addition-elimination, elimination-addition and ring opening, as well as proton abstraction reactions followed by nucleophilic substitution. The nature of the pyridine rings and bases employed plays an important role in the course of reactions [23]. 
It should also be noted that, despite the fact that fluorine- and trifluoromethyl-substituted pyridines have been very extensively studied, there are very limited data on 2- and 4-(fluoromethyl)pyridines in the literature [24-29], which makes these compounds attractive for investigations.

In our previous works, we reported a new electrophilic fluorination reaction of 1,4-dihydropyridines, providing an approach to previously unknown fluorinated 2,6-heptanediones as useful synthons for the preparation of fluorine-containing compounds. The use of 2,6-heptanediones in reactions with ammonia, amines or hydrazine hydrate offered new fluorine-containing carbocycles and heterocycles, such as 3-acetyl-5-(alkyloxycarbonyl)-3,5-difluoro-2,6-dioxo-4-phenylcyclohexan-1-ides, 2-oxa-6-azabicyclo[2.2.2]octanes and pyrazolinone derivatives [30,31].

The 1,2-dihydropyridines are known in particular for their ability to readily undergo oxidation to the pyridines [32]. Thus, isomerisation involving hydride transfer was shown to convert 1,2-dihydropyridines into their 1,4-isomers in the presence of the transition metal complex $\mathrm{RhCl}\left(\mathrm{PPh}_{3}\right)_{2}$ [33]. Polysubstituted 1,2-dihydropyridines have been found to undergo [4+2] cycloaddition as reactive dienes with maleic anhydride, dimethyl fumarate and methyl acrylate, leading to the formation of 2-azabicyclo[2.2.2]oct-7-enes [34]. The regiospecific 1,3-dipolar cycloaddition reaction of 1,2-dihydropyridines with cyanogen azide and per(poly)fluoroalkanesulfonyl azides has afforded corresponding 2,7-diazabicyclo[4.1.0]hept-4-enes and $N-(1,2,3,6$-tetrahydropyridylidene)fluoroalkanesulfonylamides $[35,36]$. The alkylation and acylation reactions of 2-alkyl(phenyl)-1-lithio-1,2-dihydropyridines has also been investigated [37-40].

It has to be noted that, to the best of our knowledge, there are no previous studies on the fluorination reactions of 1,2-dihydropyridines. In this paper, we studied the electrophilic fluorination reaction of 1,2-dihydropyridines $\mathbf{1 a - k}$ with Selectfluor ${ }^{\circledR}$ (Table 1).

Table 1. The reaction of 1,2-dihydropyridines $1 \mathbf{a}-\mathbf{k}$ with Selectfluor ${ }^{\circledR}$.<smiles>[R]C1=C([12F])C([R])C(C(=O)O[AlH2])=C([R])N1</smiles>

1a-k

$$
\text { Selectfluor }{ }^{\circledR}, 1 \text { equiv. }
$$$$
10 \mathrm{~min}, 0^{\circ} \mathrm{C}
$$

$\mathrm{MeCN}$<smiles>[R]C1=NC([Al])([Al])C([R])=C([R])C1(F)C(=O)O[AlH2]</smiles>

2a-k

\begin{tabular}{|c|c|c|c|c|c|c|c|}
\hline Comp. & $\mathbf{R}$ & Alk & $\mathbf{R}^{\prime}$ & $\mathbf{R}^{\prime \prime}$ & Ar & $\begin{array}{c}\text { The Ratio of } \\
\text { Diastereomers, } \% 1\end{array}$ & Yield, $\%^{2}$ \\
\hline $2 a$ & $\mathrm{Me}$ & $\mathrm{Me}$ & $\mathrm{H}$ & $\mathrm{NO}_{2}$ & $\mathrm{Ph}$ & $45: 55$ & 94 \\
\hline $2 b$ & $\mathrm{Me}$ & $\mathrm{Me}$ & $\mathrm{H}$ & $\mathrm{NO}_{2}$ & $\mathrm{Ph}-\mathrm{Ph}$ & $40: 60$ & 96 \\
\hline $2 c$ & $\mathrm{Me}$ & $\mathrm{Me}$ & $\mathrm{H}$ & $\mathrm{NO}_{2}$ & $o$-OMe-Ph & $45: 55$ & 90 \\
\hline $2 d$ & $\mathrm{Me}$ & $\mathrm{Me}$ & $\mathrm{H}$ & $\mathrm{NO}_{2}$ & 3,4,5-OMe-Ph & $20: 80$ & 90 \\
\hline $2 e$ & Et & $\mathrm{Me}$ & $\mathrm{H}$ & $\mathrm{NO}_{2}$ & $o$-OMe-Ph & $50: 50$ & 97 \\
\hline $2 f$ & $\mathrm{Me}$ & $\mathrm{Me}$ & $\mathrm{H}$ & $\mathrm{NO}_{2}$ & $p-\mathrm{NO}_{2}-\mathrm{Ph}$ & $50: 50$ & 94 \\
\hline $2 g$ & $\mathrm{Me}$ & $\mathrm{Me}$ & $\mathrm{H}$ & $\mathrm{NO}_{2}$ & $m-\mathrm{F}-\mathrm{Ph}$ & $50: 50$ & 88 \\
\hline $2 \mathrm{~h}$ & $\mathrm{Me}$ & $\mathrm{Me}$ & $\mathrm{H}$ & $\mathrm{NO}_{2}$ & 1,3-Ph-1H-pyrazol-4-yl & $10: 90$ & 89 \\
\hline $2 k$ & $\mathrm{Me}$ & Et & $\mathrm{Me}$ & COOEt & $\mathrm{Ph}$ & $15: 85$ & 82 \\
\hline
\end{tabular}

${ }^{1}$ The ratio of diastereomers is determined according to the ${ }^{19} \mathrm{~F},{ }^{1} \mathrm{H}-\mathrm{NMR}$ spectra of compounds $\mathbf{2 a}-\mathbf{k} .{ }^{2}$ The yields of $\mathbf{2} \mathbf{a}-\mathbf{k}$ after extraction with diethyl ether are given.

\section{Results and Discussion}

Starting 2-methyl-5-nitro-1,2-dihydropyridines 1 were obtained by the cyclisation of corresponding nitrodienamines with aldehydes [41]. We show that 1,2-dihydropyridines $\mathbf{1 a}-\mathbf{k}$ reacted with Selectfluor ${ }^{\circledR}$ at $0{ }^{\circ} \mathrm{C}$ in dry acetonitrile under an argon atmosphere to form a series of new 3-fluoro-3,6-dihydropyridines $\mathbf{2 a - k}$ (Table 1).

Products $\mathbf{2 a}-\mathbf{k}$ were isolated as mixtures of two diastereomers. The ratio of diastereomers was determined according to the ${ }^{19} \mathrm{~F},{ }^{1} \mathrm{H}-\mathrm{NMR}$ spectra of compounds $\mathbf{2 a}-\mathbf{k}$ (Table 1 ). The attempts to 
separate the diastereomers by column chromatography failed, as during separation the formation of corresponding pyridines $\mathbf{3 a - k}$ occurred as a result of the removal of hydrogen fluoride (according to LC-MS data) (Table 2).

It was found that after the storage of 3-fluoro-3,6-dihydropyridines $\mathbf{2 a - k}$ in deuterochloroform solution at room temperature for 2-4 days, hydrogen fluoride was eliminated, leading to the formation of corresponding pyridines $3 \mathbf{a}-\mathbf{k}$ (Table 2). Compounds $3 \mathbf{a}-\mathbf{k}$ were isolated by column chromatography in $72-91 \%$ yields (Table 2 ).

Table 2. The formation of pyridines $3 \mathbf{a}-\mathbf{k}$ from 3-fluoro-3,6-dihydropyridines $\mathbf{2 a - k}$ after the elimination of hydrogen fluoride.<smiles></smiles>

\begin{tabular}{ccccccc}
\hline Comp. & $\mathbf{R}$ & $\mathbf{A l k}$ & $\mathbf{R}^{\prime}$ & $\mathbf{R}^{\prime \prime}$ & $\mathbf{A r}$ & Yield, $\mathbf{\%}^{\mathbf{1}}$ \\
\hline 3a & $\mathrm{Me}$ & $\mathrm{Me}$ & $\mathrm{H}$ & $\mathrm{NO}_{2}$ & $\mathrm{Ph}$ & 91 \\
3b & $\mathrm{Me}$ & $\mathrm{Me}$ & $\mathrm{H}$ & $\mathrm{NO}_{2}$ & $\mathrm{Ph}-\mathrm{Ph}$ & 85 \\
3c & $\mathrm{Me}$ & $\mathrm{Me}$ & $\mathrm{H}$ & $\mathrm{NO}_{2}$ & o-OMe-Ph & 72 \\
3d & $\mathrm{Me}$ & $\mathrm{Me}$ & $\mathrm{H}$ & $\mathrm{NO}_{2}$ & 3,4,5-OMe-Ph & 84 \\
3e & $\mathrm{Et}$ & $\mathrm{Me}$ & $\mathrm{H}$ & $\mathrm{NO}_{2}$ & 0 -OMe-Ph & 82 \\
3f & $\mathrm{Me}$ & $\mathrm{Me}$ & $\mathrm{H}$ & $\mathrm{NO}_{2}$ & $p-\mathrm{NO}_{2}-\mathrm{Ph}$ & 93 \\
3g & $\mathrm{Me}$ & $\mathrm{Me}$ & $\mathrm{H}$ & $\mathrm{NO}_{2}$ & $m$-F-Ph & 87 \\
3h & $\mathrm{Me}$ & $\mathrm{Me}$ & $\mathrm{H}$ & $\mathrm{NO}_{2}$ & 1,3-Ph-1H-pyrazol-4-yl & 79 \\
3k & $\mathrm{Me}$ & $\mathrm{Et}$ & $\mathrm{Me}$ & $\mathrm{COOEt}$ & $\mathrm{Ph}$ & 85 \\
\hline \multicolumn{6}{c}{ Isolated yields are given. }
\end{tabular}

The effect of various factors on the course of this reaction, such as the solvent, the order of addition of reagents, temperature and dilution, was studied. Acetonitrile turned out to be the best solvent for the preparation of 3-fluoro-3,6-dihydropyridines $\mathbf{2 a - k}$. Finally, the optimal reaction conditions for the synthesis of fluorinated 3,6-dihydropyridines $2 \mathbf{a}-\mathbf{k}$ were when the solution of Selectfluor ${ }^{\circledR}$ in acetonitrile was slowly added to the solution of 1,2-dihydropyridines $\mathbf{1 a}-\mathbf{k}$ in acetonitrile under an argon atmosphere at $0{ }^{\circ} \mathrm{C}$. Compounds $\mathbf{2 a}-\mathbf{k}$ obtained by this method were further used without additional purification. In other cases, a mixture of 3-fluoro-3,6-dihydropyridines $\mathbf{2} \mathbf{a}-\mathbf{k}$ and pyridines $\mathbf{3 a}-\mathbf{k}$ as products of the elimination of hydrogen fluoride from 3-fluoro-3,6-dihydropyridines $\mathbf{2}$ was formed, according to LC-MS data.

The structures of compounds $\mathbf{2 a}-\mathbf{k}$ were established and confirmed on the base of one-dimensional ${ }^{1} \mathrm{H},{ }^{19} \mathrm{~F},{ }^{13} \mathrm{C}$ and two-dimensional $\left\{{ }^{1} \mathrm{H}-{ }^{1} \mathrm{H}\right\} \mathrm{COSY},\left\{{ }^{13} \mathrm{C}-{ }^{1} \mathrm{H}\right\}$ HSQC and $\left\{{ }^{13} \mathrm{C}-{ }^{1} \mathrm{H}\right\}$ HMBC NMR spectral data (Table 3).

The correlations of the protons at 5.4-6.2 ppm in the $\left\{{ }^{13} \mathrm{C}-{ }^{1} \mathrm{H}\right\} \mathrm{HMBC}$ spectra with the ipso and orto carbon atoms and aryl substituent for both diastereomers of compounds $\mathbf{2 a}-\mathbf{k}$ indicate that the mentioned proton and aryl substituent are located at the same C6 carbon atom.

In both diastereomers of compounds $\mathbf{2} \mathbf{a}-\mathbf{k}$, the fluorine atom and ester moiety are located at the same C3 carbon atom, as is evidenced by the large values of the constants ${ }^{1} J_{\mathrm{C} 3-\mathrm{F}}=189.1-194.2 \mathrm{~Hz}$ for the $\mathrm{C} 3$ carbon atom at $84.7-87.0 \mathrm{ppm}$ and ${ }^{2} J_{\mathrm{C}-\mathrm{F}}=26.2-30.7 \mathrm{~Hz}$ for the carbonyl carbon atom at 165.5-166.7 ppm according to the ${ }^{13} \mathrm{C}-\mathrm{NMR}$ spectra.

In the ${ }^{19} \mathrm{~F}-\mathrm{NMR}$ spectra of compounds $\mathbf{2} \mathbf{a}-\mathbf{k}$, a signal of the fluorine atom appears as a doublet doublet in the range of $-139.9 \mathrm{ppm}$ to $-145.9 \mathrm{ppm}$ with the constants ${ }^{5} J_{\mathrm{F}-\mathrm{H}}=14.0-17.0 \mathrm{~Hz}$ and 
${ }^{3} J_{\mathrm{F}-\mathrm{H}}=9.0-9.5 \mathrm{~Hz}$ for one diastereomer and in the field of $-141.5 \mathrm{ppm}$ to $-150.4 \mathrm{ppm}$ with the constants ${ }^{5} J_{\mathrm{F}-\mathrm{H}}=11.4-12.6 \mathrm{~Hz}$ and ${ }^{3} \mathrm{~J}_{\mathrm{F}-\mathrm{H}}=5.4-6.5 \mathrm{~Hz}$ for another diastereomer (Table 3).

An interesting fact is that compounds $2 \mathbf{a}-\mathbf{k}$ in the ${ }^{1} \mathrm{H}$ and ${ }^{19} \mathrm{~F}-\mathrm{NMR}$ spectra have unusually large coupling constants between the fluorine atom and $\mathrm{C} 6 \mathrm{H}$ proton, which are separated by five bonds $\left({ }^{5} J\left({ }^{19} \mathrm{~F},{ }^{1} \mathrm{H}\right)\right)$. The case of considerably large coupling across five bonds is unusual, however, it can be observed under favourable circumstances [42]. The value of this constant is almost two times higher than the constant between the fluorine nuclei and $\mathrm{C} 4 \mathrm{H}$ protons separated by only three bonds $\left({ }^{3} J_{\mathrm{F}-\mathrm{H}}=5.4-9.5 \mathrm{~Hz}\right)\left({ }^{3} J\left({ }^{19} \mathrm{~F},{ }^{1} \mathrm{H}\right)\right.$ in compounds $\mathbf{2 a}-\mathbf{h}$ (Table 3$)$.

To prove the coupling between the fluorine atom and $\mathrm{C} 6 \mathrm{H}$ proton, heteronuclear spin decoupling was used. Figure 1 shows the effect of the heteronuclear spin decoupling of the ${ }^{19} \mathrm{~F}$ nucleus on the $\mathrm{C} 6 \mathrm{H}$ and $\mathrm{C} 4 \mathrm{H}$ proton signals of compound 2a. In the below spectrum (Figure 1), the signals of the $\mathrm{C} 4 \mathrm{H}$ protons are presented as two doublet doublets coupled with the fluorine atom and $\mathrm{C} 6 \mathrm{H}$ proton $\left({ }^{4} J_{\mathrm{H}-\mathrm{H}} \sim 1.3 \mathrm{~Hz}\right)$. The $\mathrm{C} 6 \mathrm{H}$ proton is coupled with the fluorine atom through five bonds (Table 3), as well as with the $\mathrm{C} 4 \mathrm{H}$ and $\mathrm{C}_{2} \mathrm{CH}_{3}$ protons $\left({ }^{4} J_{\mathrm{H}-\mathrm{H}}<1.9 \mathrm{~Hz}\right.$ ). In the above spectrum (Figure 1), the fluorine atom is irradiated and the doublet of doublets of the $\mathrm{C} 4 \mathrm{H}$ and the multiplet of $\mathrm{C} 6 \mathrm{H}$ are collapsed to broaden singlets. The $\mathrm{C} 4 \mathrm{H}$ and $\mathrm{C} 6 \mathrm{H}$ proton signal broadening results from long-range coupling with the mentioned protons. The main information obtained from the ${ }^{19} \mathrm{~F}$ decoupling is the confirmation of the coupling between the fluorine atom and $\mathrm{C} 4 \mathrm{H}$ and $\mathrm{C} 6 \mathrm{H}$ protons.

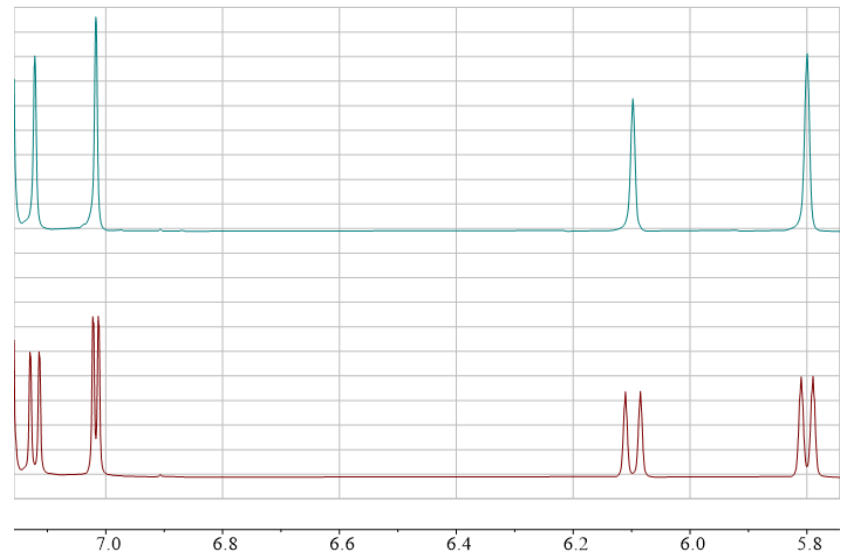

Figure 1. The $600 \mathrm{MHz}^{1} \mathrm{H}-\mathrm{NMR}$ spectrum of $\mathbf{2 a}$ in $\mathrm{CDCl}_{3}$ (red-spectra without decoupling, cyan-with ${ }^{19} \mathrm{~F}$ decoupled irradiated ${ }^{19} \mathrm{~F}$ atoms $\left({ }^{1} \mathrm{H}-\left\{{ }^{19} \mathrm{~F}\right\}\right)$.

Our attempts to explain the origin of the large coupling constant ${ }^{5} J\left({ }^{19} \mathrm{~F},{ }^{1} \mathrm{H}\right)$ value in compounds 2a-k were initially based on the hypothesis of through-space coupling for the spatially proximate $\mathrm{C} 6 \mathrm{H}$ proton and F nuclei. The evidence for the through-space mechanism in HF couplings was known previously [43-45]. The through-space mechanism is possible for compounds where the fluorine and a coupled proton are separated by a distance which does not exceed the sum of their van der Waals radii $(\sim 2.6 \AA)$.

To ascertain the possibility of through-space proton-fluorine interactions in compounds $\mathbf{2 a}-\mathbf{k}$, $\mathrm{ab}$ initio calculations were carried out and the data are presented in Table 4.

According to the quantum chemical calculations, the angles between the $\mathrm{C} 6-\mathrm{N} 1-\mathrm{C} 2-\mathrm{C} 3$ and C6-C5-C4-C3 planes are 167.8-178.5 for compounds $\mathbf{2 a - k}$ (Figure 2, Table 4), which indicate that the 3,6-dihydropyridine ring is planar or near planar. According to Table 3, the only non-planar conformer was $2 \mathbf{k}$ cis $\left(\alpha=148.2^{\circ}\right)$. It has already been established that the 1,4-cyclohexadiene ring is also relatively flat and for various cyclohexadiene derivatives $\alpha=166-172^{\circ}$ [46-49]. 
Table 3. The general NMR spectral characteristics of 3-fluoro-3,6-dihydropyridines $\mathbf{2 a - k}$.

\begin{tabular}{|c|c|c|c|c|c|c|c|c|c|c|c|}
\hline \multirow[t]{2}{*}{ Comp. } & \multirow[t]{2}{*}{$\begin{array}{l}\text { The Ratio of } \\
\text { Diastereo-mers, } \% 1\end{array}$} & \multicolumn{2}{|c|}{$\begin{array}{c}\delta \mathrm{C} 6 \mathrm{H} \text { Proton for Both } \\
\text { Diastereomers in } \\
{ }^{1} \mathrm{H}-\mathrm{NMR} \text { Spectra, ppm }\end{array}$} & \multicolumn{2}{|c|}{$\begin{array}{c}\delta \mathrm{F} \text { for both } \\
\text { Diastereomers in } \\
{ }^{19} \mathrm{~F}-\mathrm{NMR} \text { Spectra, ppm }\end{array}$} & \multicolumn{2}{|c|}{$\begin{array}{l}\text { Homoallylic Coupling } \\
\text { Constant }{ }^{5} J_{\mathrm{H}-\mathrm{F}(\mathrm{F}-\mathrm{H})} \text { for } \\
\text { Both Diastereomers, } \mathrm{Hz}^{2}\end{array}$} & \multicolumn{2}{|c|}{$\begin{array}{c}{ }^{3} J_{\mathrm{H}-\mathrm{F}(\mathrm{F}-\mathrm{H})} \text { for Both } \\
\text { Diastereomers, } \mathrm{Hz}^{2}\end{array}$} & \multicolumn{2}{|c|}{$\begin{array}{c}\text { Allylic Coupling } \\
\text { Constant }{ }^{4} J_{\mathrm{H}-\mathrm{H}} \text { for both } \\
\text { Diastereomers, } \mathrm{Hz}^{3}\end{array}$} \\
\hline & & Minor & Major & Minor & Major & Minor & Major & Minor & Major & Minor & Major \\
\hline $2 a$ & $45: 55$ & 6.09 & 5.79 & -140.6 & -142.4 & 15.4 & 12.1 & 9.4 & 5.6 & 1.3 & 1.2 \\
\hline $2 b$ & $40: 60$ & 6.22 & 5.94 & -140.3 & -142.4 & 15.4 & 12.1 & 9.3 & 5.6 & 1.2 & 1.2 \\
\hline $2 c$ & $45: 55$ & 6.70 & 6.22 & -139.9 & -144.3 & 16.6 & 12.6 & 9.0 & 6.2 & 1.4 & 1.6 \\
\hline $2 d$ & $20: 80$ & 5.79 & 6.02 & -141.5 & -140.4 & 12.2 & 15.8 & 5.4 & 9.2 & 1.1 & 1.2 \\
\hline $2 e$ & $50: 50$ & 6.72 & 6.21 & -140.5 & -145.1 & 17.0 & 12.6 & 9.1 & 6.5 & 1.2 & 1.6 \\
\hline $2 f$ & $50: 50$ & 6.26 & 5.94 & -141.6 & -143.0 & 14.4 & 11.4 & 9.5 & 5.7 & 1.1 & 1.3 \\
\hline $2 g$ & $50: 50$ & 6.16 & 5.85 & -140.7 & -142.8 & 14.9 & 11.8 & 9.4 & 5.6 & 1.1 & 1.2 \\
\hline $2 \mathrm{~h}$ & $10: 90$ & 6.05 & 6.30 & -144.2 & -142.6 & 11.9 & 14.0 & 5.8 & 9.5 & 1.5 & 1.1 \\
\hline $2 k$ & $15: 85$ & 5.38 & 5.70 & -150.4 & -145.9 & 12.0 & 15.5 & - & - & - & - \\
\hline
\end{tabular}

${ }^{1}$ The ratio of diastereomers is determined according to the ${ }^{19} \mathrm{~F},{ }^{1} \mathrm{H}-\mathrm{NMR}$ spectra of compounds $2 \mathbf{a}-\mathbf{k} .{ }^{2}$ Determined according to the ${ }^{19} \mathrm{~F},{ }^{1} \mathrm{H}-\mathrm{NMR}$ spectra of compounds $\mathbf{2 a - k} .{ }^{3}$ Determined according to the ${ }^{1} \mathrm{H}-\mathrm{NMR}$ spectra of compounds $\mathbf{2} \mathbf{a}-\mathbf{k}$.

Table 4. Quantum chemical calculation data for compounds $2 \mathbf{a}-\mathbf{k}$.

\begin{tabular}{|c|c|c|c|c|c|c|c|c|}
\hline \multirow[t]{2}{*}{ Comp. } & \multicolumn{2}{|c|}{$\mathrm{d}(\mathrm{H} \ldots \mathrm{F}), \AA$} & \multicolumn{2}{|c|}{ d(C6 to N1-C2-C4-C5 plane), Å } & \multicolumn{2}{|c|}{ d(C3 to N1-C2-C4-C5 plane), $\AA$} & \multicolumn{2}{|c|}{$\begin{array}{c}\text { The angle between C6-N1-C2-C3 } \\
\text { and C6-C5-C4-C3 Planes, }\end{array}$} \\
\hline & cis & trans & cis & trans & cis & trans & cis & trans \\
\hline $2 a$ & 4.60 & 4.73 & 0.11 & 0.11 & 0.12 & 0.13 & 169.38 & 168.88 \\
\hline $2 b$ & 4.60 & 4.85 & 0.11 & 0.02 & 0.13 & 0.05 & 169.18 & 178.46 \\
\hline $2 c$ & 4.59 & 4.85 & 0.10 & 0.01 & 0.13 & 0.08 & 169.72 & 175.66 \\
\hline $2 d$ & 4.61 & 4.72 & 0.12 & 0.12 & 0.13 & 0.15 & 168.90 & 167.86 \\
\hline $2 e$ & 4.57 & 4.77 & 0.09 & 0.07 & 0.12 & 0.07 & 170.45 & 173.73 \\
\hline $2 f$ & 4.59 & 4.85 & 0.10 & 0.03 & 0.13 & 0.10 & 169.74 & 174.07 \\
\hline $2 \mathrm{~g}$ & 4.60 & 4.85 & 0.11 & 0.01 & 0.13 & 0.08 & 169.40 & 175.94 \\
\hline $2 \mathrm{~h}$ & 4.63 & 4.77 & 0.13 & 0.08 & 0.14 & 0.08 & 167.81 & 172.97 \\
\hline $2 k$ & 4.98 & 4.80 & 0.30 & 0.02 & 0.42 & 0.05 & 148.20 & 176.79 \\
\hline
\end{tabular}


The distance between the proton and the fluorine in cis conformer is shorter than in trans for 5-nitro-substituted 3,6-dihydropyridines $\mathbf{2} \mathbf{a}-\mathbf{h}$. The distance from the C3 and C6 carbons to the N1-C2-C4-C5 plane is larger in its cis conformer (except $\mathbf{2 a}$ and $\mathbf{2 d}$ compounds) (Table 4).

The graphical representation of the optimised molecular geometry for both diastereomers of compound 2a, obtained with density-functional theory (DFT) calculations, is shown in Figure 2.

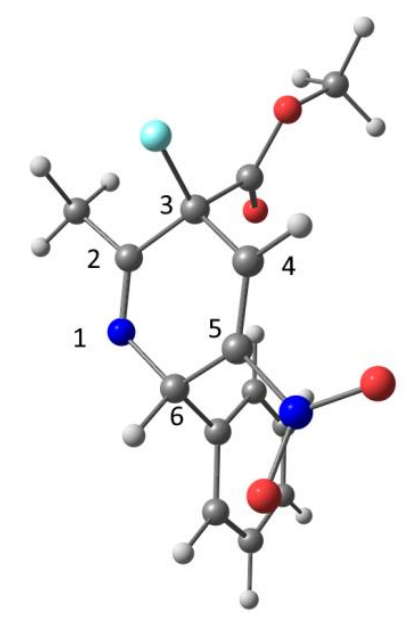

cis isomer of $\mathbf{2 a}$

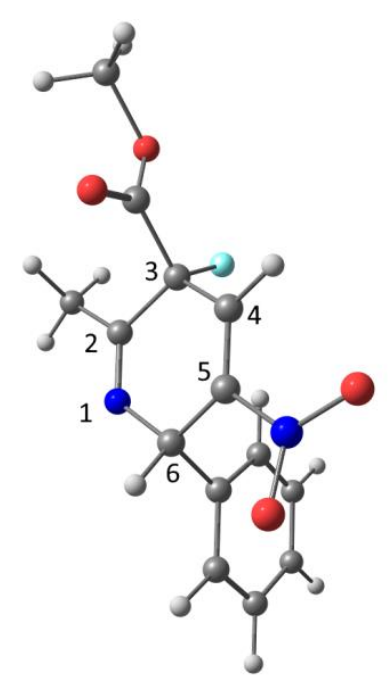

trans isomer of $\mathbf{2 a}$

Figure 2. The structure of 2a optimised by density-functional theory (DFT) calculations. The optimised structures of $\mathbf{2} \mathbf{b}-\mathbf{k}$ are provided in the Supplementary Materials as Gaussian output files.

The data show that 3,6-dihydropyridines 2 are nearly planar and the distance between the two coupled atoms $(\mathrm{C} 6 \mathrm{H}$ proton and $\mathrm{F})$ greatly exceeds the sum of the van der Waals radii varying in the interval 4.6-5.0 $\AA$ for compounds $2 \mathbf{a}-\mathbf{k}$ (Table 4). Consequently, we can claim that the transfer of spin-spin interaction through-space is rather problematic for compounds 2 . The hypothesis about homoallyl long-range coupling transmitted through $\pi$-electrons across a double bond of the heterocycle in compounds $\mathbf{2 a - k}$ seems to be more likely as compared with through-space interaction. The homoallylic coupling occurs over five bonds and attains a maximum value when the bonds to the coupled atoms are nearly parallel. The coupling is optimal when both C-H and C-F bonds are aligned with the $\pi$-orbital of an intervening double bond (perpendicular to the plane of the double bond) [49].

Extremally large homoallyl long-range $\mathrm{HH}$ couplings have been previously observed for 1,4-cyclohexadienes and related structures, where there were two paths for the coupling [50]. For planar 1,4-cyclohexadienes and their derivatives, the value of the ${ }^{5} \mathrm{JH}_{\mathrm{H} \text {-His }}$ is greater $(9.6-11.0 \mathrm{~Hz})$ than the ${ }^{5} J_{\mathrm{H}-\mathrm{H} \text { trans }}(7.5-8.4 \mathrm{~Hz})$ [49]. Based on these data, we can also suggest that the cis diastereomer of compounds $\mathbf{2} \mathbf{a}-\mathbf{k}$ has a larger homoallylic coupling constant ${ }^{5} J_{\mathrm{F}-\mathrm{H}}$ than the corresponding trans diastereomer.

We can propose the following scheme for the formation of 3-fluoro-3,6-dihydropyridines 2a-k. At the first stage of the reaction, Selectfluor ${ }^{\circledR}$ is probably attached to the double bond of 1,2-dihydropyridines $\mathbf{1} \mathbf{a}-\mathbf{k}$ with the formation of ammonium salts $\mathbf{4}$. The decomposition of these salts $\mathbf{4}$ under mild conditions results in the formation of 3-fluoro-3,6-dihydropyridines $\mathbf{2 a - k}$ (Scheme 1). 


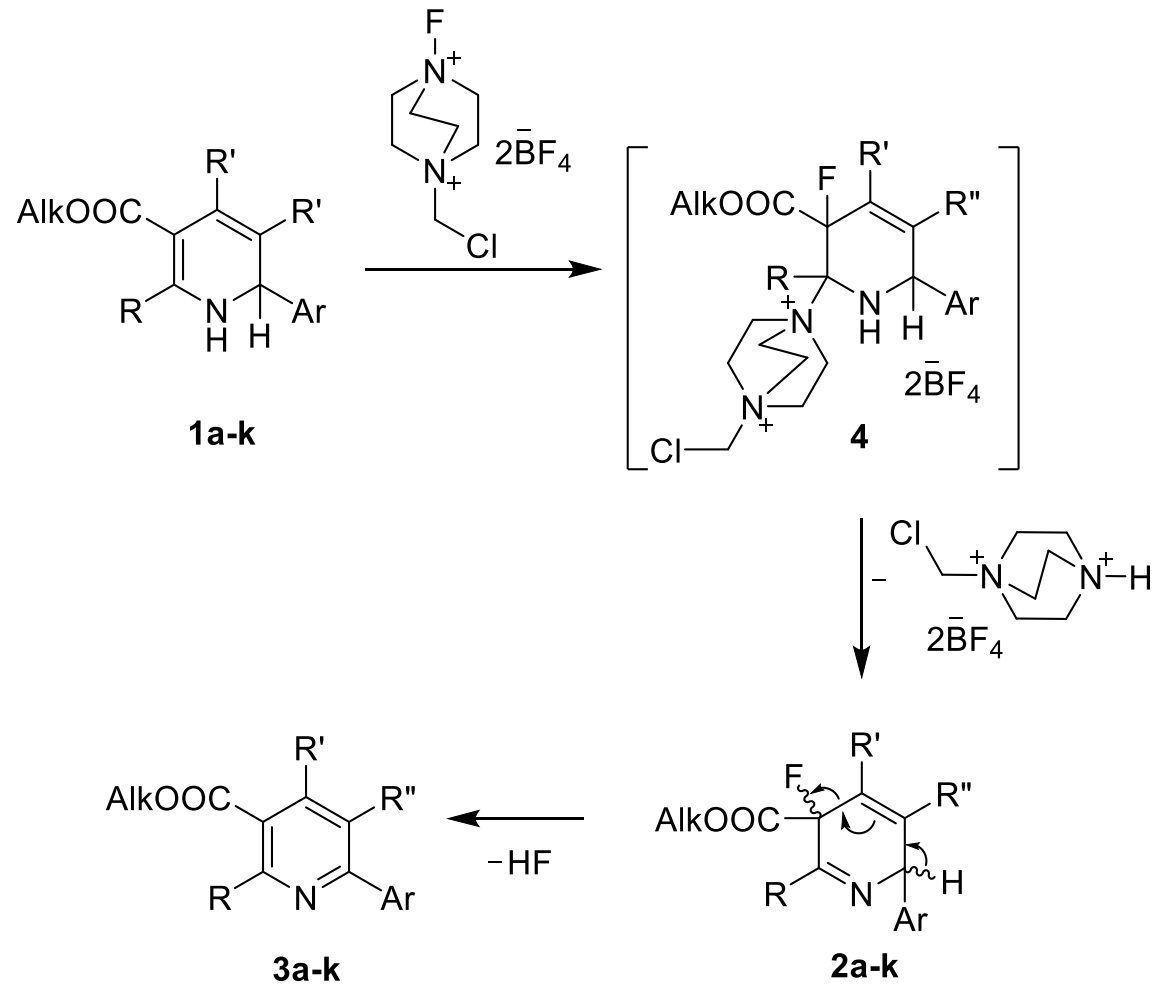

Scheme 1. Supposed scheme for the formation of 3-fluoro-3,6-dihydropyridines $2 \mathbf{a}-\mathbf{k}$ and pyridines $\mathbf{3 a}-\mathbf{k}$.

The reaction of 3-fluoro-2-methyl-5-nitro-3,6-dihydropyridines $2 \mathbf{a}, \mathbf{c}, \mathbf{f}, \mathbf{g}$ with Selectfluor ${ }^{\circledR}$ was also investigated. It was found that this reaction with 2 equiv. of Selectfluor ${ }^{\circledR}$ led to the formation of a mixture of new methyl 2-(fluoromethyl)-5-nitro-6-arylnicotinates 5a-d and 2-methylpyridines

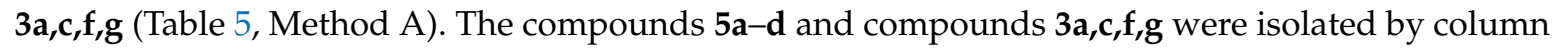
chromatography in $21-43 \%$ and $10-52 \%$ yields, respectively. Our attempts to optimise the reaction conditions, such as the solvent, the order of addition of reagents, temperature and dilution, did not lead to an increase in the yields of compounds $5 \mathbf{a}-\mathbf{d}$. The one-pot reaction of 1,2-dihydropyridines $\mathbf{1 a}, \mathbf{c}, \mathbf{f}, \mathbf{g}$ with 3 equiv. of Selectfluor ${ }^{\circledR}$, in this case omitting the isolation of 3,6-dihydropyridines $\mathbf{2 a}, \mathbf{c}, \mathbf{f}, \mathbf{g}$, directly formed 2-(fluoromethyl)pyridines 5a-d and 2-methylpyridines 3a,c,f,g (Table 5, Method B). The ratios of compounds $\mathbf{3} \mathbf{a}, \mathbf{c}, \mathbf{f}, \mathbf{g}$ and $\mathbf{5 a}-\mathbf{d}$ were determined according to the ${ }^{1} \mathrm{H}-\mathrm{NMR}$ spectra and the LC-MS data of the reaction mixture were similar to those obtained by Method A (Table 5).

It is known that N-F fluorinating agents and, in particular Selectfluor ${ }^{\circledR}$, are also strong oxidants, and competition between fluorofunctionalisation and oxidation can occur. The selectivity of fluorination reactions may thereby be decreased if the structure of the substrate contains oxidisable functional groups or heteroatoms. In our case, the reaction of 3-fluoro-2-methyl-5-nitro-3,6-dihydropyridines $\mathbf{2 a , c , f}, \mathbf{f} \mathbf{g}$ with Selectfluor ${ }^{\circledR}$ can proceed in two competitive directions. Tautomers of 3-fluoro-3,6-dihydropyridines 2 with an enamine-like structure are probably fluorinated by Selectfluor ${ }^{\circledR}$ on the methylene site of the enamine to form ammonium salts 6 (Scheme 2, Path B). The decomposition of these salts $\mathbf{6}$, followed by the elimination of hydrogen fluoride, leads to the formation of 2-(fluoromethyl)pyridines $\mathbf{5 a}-\mathbf{d}$ (Scheme 2).

On the other hand, 2-methylpyridines $3 \mathbf{a}, \mathbf{c}, \mathbf{f}, \mathbf{g}$ can be formed as a result of the elimination of hydrogen fluoride from 3-fluoro-2-methyl-5-nitro-3,6-dihydropyridines 2a,c,f,g. (Scheme 2, Path A). Under similar conditions, pyridines 3 did not react with Selectfluor ${ }^{\circledR}$. 
Table 5. Reactions of 3-fluoro-2-methyl-5-nitro-3,6-dihydropyridines 2a,c,f,g or 1,2-dihydropyridines 1a,c,f,g with Selectfluor ${ }^{\circledR}$, leading to the formation of a mixture of methyl 2-(fluoromethyl)-5-nitro-6-arylnicotinates 5a-d and 2-methylpyridines 3a,c,f,g.<smiles>COC(=O)C1=CC([N+](=O)[O-])=C(C)C(Br)C1=C(C)[Mg]</smiles>

3a,c,f,g

\begin{tabular}{cccccc}
\hline \multirow{2}{*}{ Comp. } & \multirow{2}{*}{ Ar } & \multicolumn{2}{c}{ Ratio 3:5, $\mathbf{\%}^{\mathbf{1}}$} & \multicolumn{2}{c}{ Yields, $\mathbf{\%}^{\mathbf{2}}$} \\
\cline { 3 - 6 } & & Method A & Method B & Comp. 3 & Comp. 5 \\
\hline 3a, 5a & $\mathrm{Ph}$ & $50: 50$ & $55: 45$ & 44 & 32 \\
3c, 5b & $o-\mathrm{OMe}-\mathrm{Ph}$ & $60: 40$ & $55: 45$ & 52 & 21 \\
3f, 5c & $p-\mathrm{NO}_{2}-\mathrm{Ph}$ & $15: 75$ & $20: 80$ & 10 & 38 \\
3g, 5d & $m-\mathrm{F}-\mathrm{Ph}$ & $50: 50$ & $50: 50$ & 36 & 43 \\
\hline
\end{tabular}

${ }^{1}$ The ratio of compounds $\mathbf{3 a}, \mathbf{c}, \mathbf{f}, \mathbf{g}$ to $\mathbf{5 a}-\mathbf{d}$ were determined according to the ${ }^{1} \mathrm{H}-\mathrm{NMR}$ spectra and LC-MS data of the reaction mixture. ${ }^{2}$ Isolated yields obtained by Method A are given.

There are very limited data in the literature about straightforward methods for the preparation of 2- or 4-(fluoromethyl)pyridines. When direct fluorination was performed on 4-picoline by $\mathrm{F}_{2} / \mathrm{N} 2$, 2-fluoro-4-methylpyridine was the main product [24]. Additionally, 4-(fluoromethyl)pyridine was prepared from 4-(chloromethyl)pyridine using activated tetrabutylammonium fluoride (TBAF) [25].

The preparation of 2- or 4-(fluoromethyl)pyridines was realised with $\mathrm{N}$-fluorobis (trifluoromethanesulfonyl)imide from corresponding methylpyridines in dichloromethane at room temperature. In these reactions, the presence of sodium carbonate is necessary to suppress the formation of unreactive pyridinium salts, which are generated by the strongly acidic bis(trifluoromethanesulfonyl)imide co-product [26,27].

$\mathrm{N}$-Fluorobis(trifluoromethanesulfonyl)imide, $\left(\mathrm{CF}_{3} \mathrm{SO}_{2}\right)_{2} \mathrm{NF}$, is a very attractive fluorinating agent because of its favourable physical properties and high reactivity, but it is not commercially available. In the reaction of 2-(chloromethyl)pyridine with potassium fluoride, 2-(fluoromethyl)pyridines can be also obtained (Finkelstein reaction, $\mathrm{S}_{\mathrm{N}} 2$ reaction that involves the exchange of one halogen atom for another) [28] or in the reaction of 2-pyridinylmethanol derivatives with (diethylamino)sulfur trifluoride [29].

Thus, the electrophilic fluorination reactions of 1,2-dihydropyridines 1 and 3-fluoro-2-methyl5-nitro-3,6-dihydropyridines 2 with a commercially available Selectfluor ${ }^{\circledR}$ can be used as a convenient approach for the preparation of 2-(fluoromethyl)pyridines 5 . 
<smiles>C=C1NC([Al])C([N+](=O)[O-])=CC1(F)C(=O)OC</smiles>

Scheme 2. Supposed scheme for the formation of methyl 2-(fluoromethyl)-5-nitro-6-arylnicotinates 5a-d.

\section{Materials and Methods}

\subsection{General Methods}

All reagents were purchased from Acros Organics (Geel, Belgium), Sigma-Aldrich/Merck KGaA (Darmstadt, Germany), or Alfa Aesar (Lancashire, UK) and used without further purification. TLC was performed on silica gel $60 \mathrm{~F}_{254}$ aluminium sheets $20 \times 20 \mathrm{~cm}$ (Merck KGaA, Darmstadt, Germany). Silica gel of particle size 35-70 $\mu \mathrm{m}$ (Merck KGaA, Darmstadt, Germany) was used for column chromatography. Melting points were recorded on an OptiMelt digital melting point apparatus (Stanford Research Systems, Sunnyvale, CA, USA) and were uncorrected. One-dimensional ${ }^{1} \mathrm{H},{ }^{13} \mathrm{C}$, ${ }^{19} \mathrm{~F}$ and two-dimensional $\left\{{ }^{1} \mathrm{H}-{ }^{1} \mathrm{H}\right\} \mathrm{COSY},\left\{{ }^{13} \mathrm{C}-{ }^{1} \mathrm{H}\right\} \mathrm{HMBC}$ and $\left\{{ }^{13} \mathrm{C}-{ }^{1} \mathrm{H}\right\} \mathrm{HSQC}-\mathrm{NMR}$ spectra were recorded on a Bruker Avance Neo $400 \mathrm{MHz}$ (Bruker Biospin Gmbh, Rheinstetten, Germany) with a double resonance broadband CryoProbe Prodigy $\left({ }^{1} \mathrm{H} 399.96 \mathrm{MHz},{ }^{13} \mathrm{C} 100.58 \mathrm{MHz},{ }^{19} \mathrm{~F} 376.30 \mathrm{MHz}\right)$. Inverse gate decoupling experiments for ${ }^{19} \mathrm{~F}$ on ${ }^{1} \mathrm{H}$ were recorded on a Bruker Avance Neo 600 $\mathrm{MHz}$ (Bruker Biospin Gmbh, Rheinstetten, Germany) with a quadrupole resonance CryoProbe (CP QCI 600S3 H/F-C/N-D-05 Z) $\left({ }^{1} \mathrm{H} 599.93 \mathrm{MHz},{ }^{19} \mathrm{~F} 564.44 \mathrm{MHz}\right)$. Chemical shifts of the hydrogen, carbon and fluorine atoms are presented in parts per million (ppm) and refer to the residual signals of the deuterated $\mathrm{CDCl}_{3}$ ( $\left.\delta: 7.26\right)$ solvent for the ${ }^{1} \mathrm{H}-\mathrm{NMR}$ spectra and $\mathrm{CDCl}_{3}(\delta: 77.16)$ solvent for the ${ }^{13} \mathrm{C}-\mathrm{NMR}$, respectively. For the ${ }^{19} \mathrm{~F}-\mathrm{NMR}$ experiments, indirect referencing (Bruker standard 
referencing) was used. Coupling constants $J$ are reported in hertz $(\mathrm{Hz})$. Multiplicities are abbreviated as $\mathrm{s}=$ singlet; $\mathrm{d}$ = doublet; $\mathrm{t}=$ triplet; $\mathrm{q}=$ quartet, $\mathrm{m}=$ multiplet; $\mathrm{br}=$ broad; $\mathrm{dd}$ = double doublet; $\mathrm{dm}=$ double multiplet; $\mathrm{td}=$ triple doublet; $\mathrm{ddd}=$ double double doublet. Low resolution mass spectra (MS) were determined on an Acquity UPLC system (Waters, Milford, MA, USA) connected to a Waters SQ Detector-2 operating in the electrospray ionisation (ESI) positive or negative ion mode on a Waters Acquity UPLC ${ }^{\circledR}$ BEH C18 column $(1.7 \mu \mathrm{m}, 2.1 \times 50 \mathrm{~mm}$, using gradient elution with acetonitrile $(0.01 \%$ formic acid) in water $(0.01 \%$ formic acid). High resolution mass spectra (HRMS) were determined on an Acquity UPLC H-Class system (Waters, Milford, MA, USA) connected to a Waters Synapt G2-Si operating in the ESI positive or negative ion mode on a Waters Acquity UPLC ${ }^{\circledR}$ BEH C18 column $(1.7 \mu \mathrm{m}, 2.1 \times 50 \mathrm{~mm}$, using gradient elution with acetonitrile $(0.01 \%$ formic acid) in water $(0.01 \%$ formic acid). Infrared spectra were recorded with a Prestige-21 FTIR spectrometer (Shimadzu, Kyoto, Japan). Elemental analyses were determined on an Elemental Combustion System ECS 4010 (Costech International S.p.A., Milano, Italy) at the Laboratory of Chromatography of the Latvian Institute of Organic Synthesis. All quantum chemical calculations were performed with Gaussian 09 [51]. Geometry optimisation and vibrational calculations were performed with $6-311++\mathrm{G}(\mathrm{d} 2$,p2) basis set using DFT B97D3 functional with Grimme's empirical dispersion D3 correction [52]. All geometries were optimised using the polarisable continuum model (PCM) solvation model for chloroform. For all optimised geometries, vibrational harmonic frequencies were calculated at the same level of theory, all the obtained harmonic frequencies were positive. Planes, distances to planes and angles between planes were calculated with the Mercury 3.1 program by Cambridge Crystallographic Data Centre (CCDC) (https://www.ccdc.cam.ac.uk/solutions/csd-system/components/mercury/).

\subsection{General Procedure for the Synthesis of 3-Fluoro-3,6-dihydropyridines $\mathbf{2} \boldsymbol{a}-\boldsymbol{k}$}

A solution of Selectfluor ${ }^{\circledR}(0.170 \mathrm{~g}, 0.5 \mathrm{mmol})$ in dry acetonitrile $(5 \mathrm{~mL})$ was slowly added dropwise to a solution of 1,2-dihydropyridines $1 \mathbf{a}-\mathbf{k}(0.5 \mathrm{mmol})$ in dry acetonitrile $(5 \mathrm{~mL})$ in the presence of $3 \AA$ molecular sieves at $0^{\circ} \mathrm{C}$ under an argon atmosphere. The reaction mixture was stirred for $10 \mathrm{~min}$ at $0{ }^{\circ} \mathrm{C}$, after which the temperature was slowly raised to room temperature. The reaction mixture was concentrated in vacuo to dryness, then diluted with diethyl ether $(15 \mathrm{~mL})$ and filtered. The filtrate was evaporated in vacuo to give compounds $\mathbf{2 a}-\mathbf{k}$ as oils in $82-97 \%$ yields. Compounds $\mathbf{2 a - k}$ obtained by this method were further used without additional purification.

\subsubsection{Methyl 3-fluoro-2-methyl-5-nitro-6-phenyl-3,6-dihydropyridine-3-carboxylate (2a)}

Pale yellow oil. Yield $0.137 \mathrm{~g}(94 \%)$. Mixture of diastereomers (the ratio is 45:55 according to the ${ }^{19} \mathrm{~F}$ and ${ }^{1} \mathrm{H}-\mathrm{NMR}$ spectra). ${ }^{1} \mathrm{H}-\mathrm{NMR}\left(\mathrm{CDCl}_{3}\right): \delta 2.20\left(\mathrm{~d},{ }^{4} J_{\mathrm{H}-\mathrm{F}}=2.1 \mathrm{~Hz}, 3 \mathrm{H}, \mathrm{CH}_{3}\right.$ of major diastereomer), $2.22\left(\mathrm{dd},{ }^{4} J_{\mathrm{H}-\mathrm{F}}=1.8 \mathrm{~Hz},{ }^{5} J_{\mathrm{H}-\mathrm{H}}=1.5 \mathrm{~Hz}, 3 \mathrm{H}, \mathrm{CH}_{3}\right.$ of minor diastereomer), 3.87 (s, $3 \mathrm{H}, \mathrm{COOCH}_{3}$ of minor diastereomer), 3.89 (s, 3H, $\mathrm{COOCH}_{3}$ of major diastereomer), 5.77-5.81 (dm, ${ }^{5} J_{\mathrm{H}-\mathrm{F}}=12.1 \mathrm{~Hz}, 1 \mathrm{H}, \mathrm{C} 6 \mathrm{H}$ of major diastereomer $), 6.06-6.11\left(\mathrm{dm},{ }^{5} J_{\mathrm{H}-\mathrm{F}}=15.4 \mathrm{~Hz}, 1 \mathrm{H}, \mathrm{C} 6 \mathrm{H}\right.$ of minor diastereomer), $7.09\left(\mathrm{dd},{ }^{3} \mathrm{~J}_{\mathrm{H}-\mathrm{F}}=5.6 \mathrm{~Hz},{ }^{4} \mathrm{~J}_{\mathrm{H}-\mathrm{H}}=1.2 \mathrm{~Hz}, 1 \mathrm{H}, \mathrm{C} 4 \mathrm{H}\right.$ of major diastereomer), 7.18 (dd, ${ }^{3} J_{\mathrm{H}-\mathrm{F}}=9.4 \mathrm{~Hz},{ }^{4} J_{\mathrm{H}-\mathrm{H}}=1.3 \mathrm{~Hz}, 1 \mathrm{H}, \mathrm{C} 4 \mathrm{H}$ of minor diastereomer), 7.22-7.24 (m, 1H, CH, Ph), 7.24-7.26 $(\mathrm{m}, 1 \mathrm{H}, \mathrm{CH}, \mathrm{Ph}), 7.30-7.38\left(\mathrm{~m}, 8 \mathrm{H}, \mathrm{CH}, \mathrm{Ph}\right.$ of both diastereomers). ${ }^{19} \mathrm{~F}-\mathrm{NMR}\left(\mathrm{CDCl}_{3}\right): \delta-140.6$ $\left(\mathrm{dd},{ }^{5} J_{\mathrm{F}-\mathrm{H}}=15.4 \mathrm{~Hz},{ }^{3} J_{\mathrm{F}-\mathrm{H}}=9.4 \mathrm{~Hz}, 1 \mathrm{~F}, \mathrm{CF}\right.$ of minor diastereomer $),-142.4\left(\mathrm{dd},{ }^{5} J_{\mathrm{F}-\mathrm{H}}=12.1 \mathrm{~Hz}\right.$, ${ }^{3} J_{\mathrm{F}-\mathrm{H}}=5.6 \mathrm{~Hz}, 1 \mathrm{~F}, \mathrm{CF}$ of major diastereomer). ${ }^{13} \mathrm{C}-\mathrm{NMR}\left(\mathrm{CDCl}_{3}\right): \delta 20.7\left(\mathrm{~s}, \mathrm{CH}_{3}\right.$ of minor diastereomer $)$, 20.9 (s, $\mathrm{CH}_{3}$ of major diastereomer), 54.1 (s, $\mathrm{COOCH}_{3}$ of minor diastereomer), 54.2 (s, $\mathrm{COOCH}_{3}$ of major diastereomer), $61.9\left(\mathrm{~d},{ }^{4} J_{\mathrm{C}-\mathrm{F}}=3.2 \mathrm{~Hz}, \mathrm{C} 6 \mathrm{H}\right.$ of major diastereomer $), 62.5\left(\mathrm{~d},{ }^{4} J_{\mathrm{C}-\mathrm{F}}=2.7 \mathrm{~Hz}, \overline{\mathrm{C}} 6 \mathrm{H}\right.$ of minor diastereomer), $84.8\left(\mathrm{~d},{ }^{1} J_{\mathrm{C}-\mathrm{F}}=189.9 \mathrm{~Hz}, \mathrm{CF}\right.$ of major diastereomer), $87.0\left(\mathrm{~d},{ }^{1} J_{\mathrm{C}-\mathrm{F}}=191.2 \mathrm{~Hz}, \mathrm{CF}\right.$ of minor diastereomer), $120.9\left(\mathrm{~d},{ }^{2} J_{\mathrm{C}-\mathrm{F}}=27.3 \mathrm{~Hz}, \mathrm{C} 4 \mathrm{H}\right.$ of major diastereomer $), 122.3\left(\mathrm{~d},{ }^{2} J_{\mathrm{C}-\mathrm{F}}=25.9 \mathrm{~Hz}\right.$, $\mathrm{C} 4 \mathrm{H}$ of minor diastereomer), 128.0 (s, $2 \times \mathrm{CH}$, Ph of major diastereomer), 128.2 (s, $2 \times \mathrm{CH}$, Ph of minor diastereomer), 128.8 (s, CH, Ph of minor diastereomer), 128.9 (s, CH, Ph of major diastereomer), 129.0 (s, $2 \times \mathrm{CH}$, Ph of minor diastereomer), 129.3 (s, $2 \times \mathrm{CH}$, Ph of major diastereomer), $135.5\left(\mathrm{~d},{ }^{5} J_{\mathrm{C}-\mathrm{F}}=6.9 \mathrm{~Hz}\right.$, $\mathrm{C}_{\mathrm{q}}, \mathrm{Ph}$ of major diastereomer), $135.8\left(\mathrm{~d},{ }^{5} \mathrm{~J}_{\mathrm{C}-\mathrm{F}}=4.1 \mathrm{~Hz}, \mathrm{C}_{\mathrm{q}}, \mathrm{Ph}\right.$ of minor diastereomer), $154.7(\mathrm{~d}$, 
${ }^{3} J_{\mathrm{C}-\mathrm{F}}=8.7 \mathrm{~Hz}, \mathrm{C} 5$ of minor diastereomer), $155.7\left(\mathrm{~d},{ }^{3} J_{\mathrm{C}-\mathrm{F}}=8.4 \mathrm{~Hz}, \mathrm{C} 5\right.$ of major diastereomer $), 156.8(\mathrm{~d}$, ${ }^{2} J_{\mathrm{C}-\mathrm{F}}=20.9 \mathrm{~Hz}, \mathrm{C} 2$ of major diastereomer), $157.3\left(\mathrm{~d},{ }^{2} J_{\mathrm{C}-\mathrm{F}}=19.8 \mathrm{~Hz}, \mathrm{C} 2\right.$ of minor diastereomer $), 165.5$ $\left(\mathrm{d},{ }^{2} J_{\mathrm{C}-\mathrm{F}}=28.8 \mathrm{~Hz}, \mathrm{C}=\mathrm{O}\right.$ of minor diastereomer), $165.9\left(\mathrm{~d},{ }^{2} J_{\mathrm{C}-\mathrm{F}}=29.3 \mathrm{~Hz}, \mathrm{C}=\mathrm{O}\right.$ of major diastereomer). HRMS (ESI ${ }^{+}$): Calcd for $\mathrm{C}_{14} \mathrm{H}_{13} \mathrm{FN}_{2} \mathrm{O}_{4}$ [M + H]: 293.0946; found 293.0938.

3.2.2. Methyl 6-([1,1'-biphenyl]-4-yl)-3-fluoro-2-methyl-5-nitro-3,6-dihydropyridine-3-carboxylate (2b)

Pale yellow oil. Yield $0.177 \mathrm{~g}(96 \%)$. Mixture of diastereomers (the ratio is $40: 60$ according to the ${ }^{19} \mathrm{~F}$ and ${ }^{1} \mathrm{H}-\mathrm{NMR}$ spectra). ${ }^{1} \mathrm{H}-\mathrm{NMR}\left(\mathrm{CDCl}_{3}\right): \delta 2.23-2.24\left(\mathrm{dm},{ }^{4} J_{\mathrm{H}-\mathrm{F}}=1.8 \mathrm{~Hz}, 3 \mathrm{H}, \mathrm{CH}_{3}\right.$ of major diastereomer), $2.24-2.25\left(\mathrm{dm},{ }^{4} J_{\mathrm{H}-\mathrm{F}}=1.5 \mathrm{~Hz}, 3 \mathrm{H}, \mathrm{CH}_{3}\right.$ of minor diastereomer), $3.91\left(\mathrm{~s}, 3 \mathrm{H}, \mathrm{COOCH}_{3}\right.$ of minor diastereomer), $3.92\left(\mathrm{~s}, 3 \mathrm{H}, \mathrm{COOCH}_{3}\right.$ of major diastereomer $), 5.91-5.96\left(\mathrm{dm},{ }^{5} J_{\mathrm{H}-\mathrm{F}}=12.1 \mathrm{~Hz}, 1 \mathrm{H}\right.$, $\mathrm{C} 6 \mathrm{H}$ of major diastereomer), $6.20-6.25\left(\mathrm{dm},{ }^{5} \mathrm{~J}_{\mathrm{H}-\mathrm{F}}=15.4 \mathrm{~Hz}, 1 \mathrm{H}, \mathrm{C} 6 \mathrm{H}\right.$ of minor diastereomer), 7.13 $\left(\mathrm{dd},{ }^{3} J_{\mathrm{H}-\mathrm{F}}=5.6 \mathrm{~Hz},{ }^{4} J_{\mathrm{H}-\mathrm{H}}=1.2 \mathrm{~Hz}, 1 \mathrm{H}, \mathrm{C} 4 \mathrm{H}\right.$ of major diastereomer), $7.23\left(\mathrm{dd},{ }^{3} J_{\mathrm{H}-\mathrm{F}}=9.3 \mathrm{~Hz},{ }^{4} J_{\mathrm{H}-\mathrm{H}}=\right.$ $1.2 \mathrm{~Hz}, 1 \mathrm{H}, \mathrm{C} 4 \mathrm{H}$ of minor diastereomer), 7.23-7.37 (m, 4H, CH, Ar of both diastereomers), 7.41-7.46 $\left(\mathrm{m}, 6 \mathrm{H}, \mathrm{CH}, \mathrm{Ar}\right.$ of both diastereomers), $7.54-7.60\left(\mathrm{~m}, 8 \mathrm{H}, \mathrm{CH}, \mathrm{Ar}\right.$ of both diastereomers). ${ }^{19} \mathrm{~F}-\mathrm{NMR}$ $\left(\mathrm{CDCl}_{3}\right): \delta-140.3\left(\mathrm{dd},{ }^{5} J_{\mathrm{F}-\mathrm{H}}=15.4 \mathrm{~Hz},{ }^{3} J_{\mathrm{F}-\mathrm{H}}=9.3 \mathrm{~Hz}, 1 \mathrm{~F}, \mathrm{CF}\right.$ of minor diastereomer $),-142.4\left(\mathrm{dd},{ }^{5} J_{\mathrm{F}-\mathrm{H}}\right.$ $=12.1 \mathrm{~Hz},{ }^{3} J_{\mathrm{F}-\mathrm{H}}=5.6 \mathrm{~Hz}, 1 \mathrm{~F}, \mathrm{CF}$ of major diastereomer). ${ }^{13} \mathrm{C}-\mathrm{NMR}\left(\mathrm{CDCl}_{3}\right): \delta 20.9\left(\mathrm{~s}, \mathrm{CH}_{3}\right.$ of minor diastereomer), 21.0 (s, $\mathrm{CH}_{3}$ of major diastereomer), $54.2\left(\mathrm{~s}, \mathrm{COOCH}_{3}\right.$ of minor diastereomer), 54.3 (s, $\mathrm{COOCH}_{3}$ of major diastereomer), $61.7\left(\mathrm{~d},{ }^{4} J_{\mathrm{C}-\mathrm{F}}=3.2 \mathrm{~Hz}, \mathrm{C} 6 \mathrm{H}\right.$ of major diastereomer), $62.3\left(\mathrm{~d},{ }^{4} J_{\mathrm{C}-\mathrm{F}}=\right.$ $2.7 \mathrm{~Hz}, \mathrm{C} 6 \mathrm{H}$ of minor diastereomer), $84.8\left(\mathrm{~d},{ }^{1} J_{\mathrm{C}-\mathrm{F}}=189.1 \mathrm{~Hz}, \mathrm{CF}\right.$ of major diastereomer), $86.1\left(\mathrm{~d},{ }^{1} J_{\mathrm{C}-\mathrm{F}}\right.$ $=191.4 \mathrm{~Hz}, \mathrm{CF}$ of minor diastereomer), $121.2\left(\mathrm{~d},{ }^{2} J_{\mathrm{C}-\mathrm{F}}=24.3 \mathrm{~Hz}, \mathrm{C} 4 \mathrm{H}\right.$ of major diastereomer $), 122.5$ $\left(\mathrm{d},{ }^{2} J_{\mathrm{C}-\mathrm{F}}=26.3 \mathrm{~Hz}, \mathrm{C} 4 \mathrm{H}\right.$ of minor diastereomer), 127.25 (s, Ar of minor diastereomer), 127.29 (s, Ar of major diastereomer), 127.7 (s, Ar of minor diastereomer), 127.9 (s, Ar of minor diastereomer), 128.1 (s, Ar of major diastereomer), 128.5 (s, Ar of major diastereomer), 128.6 (s, Ar of minor diastereomer), 128.9 (s, Ar of major diastereomer), $134.4\left(\mathrm{~d},{ }^{5} \mathrm{~J}_{\mathrm{C}-\mathrm{F}}=7.0 \mathrm{~Hz}, \mathrm{C}_{\mathrm{q}}, \mathrm{Ar}\right.$ of major diastereomer), 134.8 (d, ${ }^{5} J_{\mathrm{C}-\mathrm{F}}=3.8 \mathrm{~Hz}, \mathrm{C}_{\mathrm{q}}$, Ar of minor diastereomer), 140.5 (s, C $\mathrm{q}$, Ar of both diastereomers), 141.8 (s, $\mathrm{C}_{\mathrm{q}}, \mathrm{Ar}$ of minor diastereomer), $142.0\left(\mathrm{~s}, \mathrm{C}_{\mathrm{q}}\right.$, Ar of major diastereomer), $154.7\left(\mathrm{~d},{ }^{3} J_{\mathrm{C}-\mathrm{F}}=9.0 \mathrm{~Hz}, \mathrm{C} 5\right.$ of minor diastereomer), $155.7\left(\mathrm{~d},{ }^{3} J_{\mathrm{C}-\mathrm{F}}=8.7 \mathrm{~Hz}, \mathrm{C} 5\right.$ of major diastereomer), $157.1\left(\mathrm{~d},{ }^{2} J_{\mathrm{C}-\mathrm{F}}=20.8 \mathrm{~Hz}, \mathrm{C} 2\right.$ of major diastereomer), $157.6\left(\mathrm{~d},{ }^{2} J_{\mathrm{C}-\mathrm{F}}=20.0 \mathrm{~Hz}, \mathrm{C} 2\right.$ of minor diastereomer $), 165.8\left(\mathrm{~d},{ }^{2} \mathrm{~J}_{\mathrm{C}-\mathrm{F}}=28.8 \mathrm{~Hz}, \mathrm{C}=\mathrm{O}\right.$ of minor diastereomer), $166.1\left(\mathrm{~d},{ }^{2} J_{\mathrm{C}-\mathrm{F}}=29.4 \mathrm{~Hz}, \mathrm{C}=\mathrm{O}\right.$ of major diastereomer). $\mathrm{HRMS}\left(\mathrm{ESI}^{+}\right)$: $\mathrm{Calcd}$ for $\mathrm{C}_{20} \mathrm{H}_{17} \mathrm{FN}_{2} \mathrm{O}_{4}[\mathrm{M}+\mathrm{H}]: 369.1251$; found 369.1264.

\subsubsection{Methyl 3-fluoro-6-(2-methoxyphenyl)-2-methyl-5-nitro-3,6-dihydropyridine-3-carboxylate (2c)}

Yellow oil. Yield $0.145 \mathrm{~g}(90 \%)$. Mixture of diastereomers (the ratio is $45: 55$ according to the ${ }^{19} \mathrm{~F}$ and ${ }^{1} \mathrm{H}-\mathrm{NMR}$ spectra). ${ }^{1} \mathrm{H}-\mathrm{NMR}\left(\mathrm{CDCl}_{3}\right): \delta 2.18-2.20\left(\mathrm{~m}, 6 \mathrm{H}, \mathrm{CH}_{3}\right.$ of both diastereomers), $3.85(\mathrm{~s}, 3 \mathrm{H}$, $\mathrm{COOCH}_{3}$ of minor diastereomer), $3.89\left(\mathrm{~s}, 3 \mathrm{H}, \mathrm{COOCH}_{3}\right.$ of major diastereomer), $3.91\left(\mathrm{~s}, 3 \mathrm{H}, \mathrm{OCH}_{3}\right.$ of minor diastereomer), $3.96\left(\mathrm{~s}, 3 \mathrm{H}, \mathrm{OCH}_{3}\right.$ of major diastereomer), $6.21-6.26\left(\mathrm{dm},{ }^{5} J_{\mathrm{H}-\mathrm{F}}=12.6 \mathrm{~Hz}\right.$, $1 \mathrm{H}, \mathrm{C} 6 \mathrm{H}$ of major diastereomer), $6.69-6.75\left(\mathrm{dm}, 5 J_{\mathrm{H}-\mathrm{F}}=16.6 \mathrm{~Hz}, 1 \mathrm{H}, \mathrm{C} 6 \mathrm{H}\right.$ of minor diastereomer), 6.84-6.89 (m, 1H, CH, Ar), 6.90-6.94 (m, 2H, $2 \times \mathrm{CH}$, Ar of both diastereomers), 6.96-7.00 (m, 2H, $\mathrm{CH}, \mathrm{Ar}$ of both diastereomers), 7.03-7.05 (m, 1H, CH, Ar), $7.07\left(\mathrm{dd},{ }^{3} J_{\mathrm{H}-\mathrm{F}}=6.2 \mathrm{~Hz},{ }^{4} J_{\mathrm{H}-\mathrm{H}}=1.6 \mathrm{~Hz}, 1 \mathrm{H}\right.$, $\mathrm{C} 4 \mathrm{H}$ of major diastereomer), $7.22\left(\mathrm{dd},{ }^{3} J_{\mathrm{H}-\mathrm{F}}=9.0 \mathrm{~Hz},{ }^{4} J_{\mathrm{H}-\mathrm{H}}=1.4 \mathrm{~Hz}, 1 \mathrm{H}, \mathrm{C} 4 \mathrm{H}\right.$ of minor diastereomer); 7.27-7.31 (m, 2H, CH, Ar of both diastereomers). ${ }^{19} \mathrm{~F}-\mathrm{NMR}\left(\mathrm{CDCl}_{3}\right): \delta-139.9\left(\mathrm{dd},{ }^{5} J_{\mathrm{F}-\mathrm{H}}=16.6 \mathrm{~Hz}\right.$, ${ }^{3} J_{\mathrm{F}-\mathrm{H}}=9.0 \mathrm{~Hz}, 1 \mathrm{~F}, \mathrm{CF}$ of minor diastereomer), $-144.3\left(\mathrm{dd},{ }^{5} J_{\mathrm{F}-\mathrm{H}}=12.6 \mathrm{~Hz},{ }^{3} J_{\mathrm{F}-\mathrm{H}}=6.2 \mathrm{~Hz}, 1 \mathrm{~F}, \mathrm{CF}\right.$ of major diastereomer). ${ }^{13} \mathrm{C}-\mathrm{NMR}\left(\mathrm{CDCl}_{3}\right): \delta 20.8\left(\mathrm{~s}, 2 \times \mathrm{CH}_{3}\right.$ of both diastereomers), $54.2\left(\mathrm{~s}, \mathrm{COOCH}_{3}\right.$ of minor diastereomer), $54.3\left(\mathrm{~s}, \mathrm{COOCH}_{3}\right.$ of major diastereomer), $55.7\left(\mathrm{~s}, \mathrm{OCH}_{3}\right.$ of major diastereomer), $55.9\left(\mathrm{~d},{ }^{4} J_{\mathrm{C}-\mathrm{F}}=2.6 \mathrm{~Hz}, \mathrm{C} 6 \mathrm{H}\right.$ of minor diastereomer), $56.2\left(\mathrm{~s}, \mathrm{OCH}_{3}\right.$ of minor diastereomer $), 56.8\left(\mathrm{~d},{ }^{4} J_{\mathrm{C}-\mathrm{F}}\right.$ $=3.2 \mathrm{~Hz}, \mathrm{C} 6 \mathrm{H}$ of major diastereomer), $86.16\left(\mathrm{~d},{ }^{1} J_{\mathrm{C}-\mathrm{F}}=190.1 \mathrm{~Hz}, \mathrm{CF}\right.$ of major diastereomer $), 86.23(\mathrm{~d}$, ${ }^{1} J_{\mathrm{C}-\mathrm{F}}=191.3 \mathrm{~Hz}, \mathrm{CF}$ of minor diastereomer), $120.86\left(\mathrm{~s}, \mathrm{Ar}\right.$ of minor diastereomer), $120.90\left(\mathrm{~d},{ }^{2} J_{\mathrm{C}-\mathrm{F}}=\right.$ $24.8 \mathrm{~Hz}, \mathrm{C} 4 \mathrm{H}$ of major diastereomer), $121.3\left(\mathrm{~s}, \mathrm{CH}, \mathrm{Ar}\right.$ of major diastereomer), $122.6\left(\mathrm{~d},{ }^{2} J_{\mathrm{C}-\mathrm{F}}=26.6 \mathrm{~Hz}\right.$, $\mathrm{C} 4 \mathrm{H}$ of minor diastereomer), 123.6 (s, Ar of major diastereomer), 125.6 (s, Ar of minor diastereomer), 127.6 (s, Ar of minor diastereomer), $129.03-129.06$ ( $m, C_{\mathrm{q}}$, Ar of minor diastereomer), 130.52-130.56 
( $\mathrm{m}, \mathrm{C}_{\mathrm{q}}$, Ar of major diastereomer), 144.7 (s, $\underline{\mathrm{C}-\mathrm{OCH}_{3}}$, Ar of both diastereomers), 155.13-155.31 (m, C5 of both diastereomers), 157.3 (s, C2 of major diastereomer), 157.4 (s, C2 of minor diastereomer), 166.0 $\left(\mathrm{d},{ }^{2} J_{\mathrm{C}-\mathrm{F}}=30.7 \mathrm{~Hz}, \mathrm{C}=\mathrm{O}\right.$ of both diastereomers $)$. MS: $m / z=323[\mathrm{M}+1](100 \%)$.

3.2.4. Methyl 3-fluoro-2-methyl-5-nitro-6-(3,4,5-trimethoxyphenyl)-3,6-dihydropyridine3-carboxylate (2d)

Yellow brown oil. Yield $0.172 \mathrm{~g}(90 \%)$. Mixture of diastereomers (the ratio is 20:80 according to the ${ }^{19} \mathrm{~F}$ and ${ }^{1} \mathrm{H}-\mathrm{NMR}$ spectra). ${ }^{1} \mathrm{H}-\mathrm{NMR}\left(\mathrm{CDCl}_{3}\right): \delta 2.21\left(\mathrm{~d},{ }^{4} J_{\mathrm{H}-\mathrm{F}}=1.7 \mathrm{~Hz}, 3 \mathrm{H}, \mathrm{CH}_{3}\right.$ of minor diastereomer), $2.24\left(\mathrm{t},{ }^{4} J_{\mathrm{H}-\mathrm{F}}=1.4 \mathrm{~Hz}, 3 \mathrm{H}, \mathrm{CH}_{3}\right.$ of major diastereomer), $3.81\left(\mathrm{~s}, 6 \mathrm{H}, \mathrm{OCH}_{3}\right.$, Ar of both diastereomers), $3.83\left(\mathrm{~s}, 6 \mathrm{H}, 2 \times \mathrm{OCH}_{3}\right.$, Ar of minor diastereomer), $3.85\left(\mathrm{~s}, 6 \mathrm{H}, 2 \times \mathrm{OCH}_{3}\right.$, Ar of major diastereomer), $3.91\left(\mathrm{~s}, 3 \mathrm{H}, \mathrm{COOC} \underline{\mathrm{H}}_{3}\right.$ of minor diastereomer), 3.94 (s, 3H, $\mathrm{COOC} \underline{\mathrm{H}}_{3}$ of major diastereomer), 5.77-5.81 $\left(\mathrm{dm},{ }^{5} J_{\mathrm{H}-\mathrm{F}}=12.2 \mathrm{~Hz}, 1 \mathrm{H}, \mathrm{C} 6 \mathrm{H}\right.$ of minor diastereomer $), 6.02-6.07\left(\mathrm{dm},{ }^{5} \mathrm{~J}_{\mathrm{H}-\mathrm{F}}=15.8 \mathrm{~Hz}, 1 \mathrm{H}, \mathrm{C} 6 \mathrm{H}\right.$ of major diastereomer), 6.43 (s, 2H, $2 \times \mathrm{CH}$, Ar of minor diastereomer), 6.62 (s, 2H, $2 \times \mathrm{CH}$, Ar of major diastereomer), $7.08\left(\mathrm{dd},{ }^{3} J_{\mathrm{H}-\mathrm{F}}=5.4 \mathrm{~Hz},{ }^{4} J_{\mathrm{H}-\mathrm{H}}=1.1 \mathrm{~Hz}, 1 \mathrm{H}, \mathrm{C} 4 \mathrm{H}\right.$ of minor diastereomer $), 7.14\left(\mathrm{dd},{ }^{3} J_{\mathrm{H}-\mathrm{F}}\right.$ $=9.2 \mathrm{~Hz},{ }^{4} J_{\mathrm{H}-\mathrm{H}}=1.2 \mathrm{~Hz}, 1 \mathrm{H}, \mathrm{C} 4 \mathrm{H}$ of major diastereomer $) .{ }^{19} \mathrm{~F}-\mathrm{NMR}\left(\mathrm{CDCl}_{3}\right): \delta-140.3\left(\mathrm{dd},{ }^{5} J_{\mathrm{F}-\mathrm{H}}=\right.$ $15.8 \mathrm{~Hz},{ }^{3} J_{\mathrm{F}-\mathrm{H}}=9.2 \mathrm{~Hz}, 1 \mathrm{~F}, \mathrm{CF}$ of major diastereomer), $-141.6\left(\mathrm{dd},{ }^{5} J_{\mathrm{F}-\mathrm{H}}=12.2 \mathrm{~Hz},{ }^{3} J_{\mathrm{F}-\mathrm{H}}=5.4 \mathrm{~Hz}, 1 \mathrm{~F}\right.$, $\mathrm{CF}$ of minor diastereomer). ${ }^{13} \mathrm{C}-\mathrm{NMR}\left(\mathrm{CDCl}_{3}\right): \delta 21.0\left(\mathrm{~s}, \mathrm{CH}_{3}\right.$ of major diastereomer), $21.1\left(\mathrm{~s}, \mathrm{CH}_{3}\right.$ of minor diastereomer), 54.3 (s, $\mathrm{COOCH}_{3}, \mathrm{Ar}$ of minor diastereomer), 54.4 (s, $\mathrm{COOCH}_{3}, \mathrm{Ar}$ of major diastereomer), 56.27 (s, $2 \times \mathrm{OCH}_{3}$ of minor diastereomer), 56.33 (s, $2 \times \mathrm{OCH}_{3}$ of minor diastereomer), 60.9 (s, $\mathrm{OCH}_{3}$ of both diastereomers), $62.1\left(\mathrm{~d},{ }^{4} J_{\mathrm{C}-\mathrm{F}}=3.4 \mathrm{~Hz}, \mathrm{C} 6 \mathrm{H}\right.$ of minor diastereomer), $62.7\left(\mathrm{~d},{ }^{4} J_{\mathrm{C}-\mathrm{F}}\right.$ $=2.8 \mathrm{~Hz}, \mathrm{C} 6 \mathrm{H}$ of major diasteeomer), $85.7\left(\mathrm{~d},{ }^{1} J_{\mathrm{C}-\mathrm{F}}=189.2 \mathrm{~Hz}, \mathrm{CF}\right.$ of minor diastereomer), $86.1\left(\mathrm{~d},{ }^{1} J_{\mathrm{C}-\mathrm{F}}\right.$ $=194.2 \mathrm{~Hz}, \mathrm{CF}$ of major diastereomer), 105.2 (s, CH, Ar of minor diasrereomer), 105.7 (s, CH, Ar of major diastereomer), $121.0\left(\mathrm{~d},{ }^{2} J_{\mathrm{C}-\mathrm{F}}=24.1 \mathrm{~Hz}, \mathrm{C} 4 \mathrm{H}\right.$ of minor diastereomer $), 121.8\left(\mathrm{~d},{ }^{2} J_{\mathrm{C}-\mathrm{F}}=25.4 \mathrm{~Hz}\right.$, $\mathrm{C} 4 \mathrm{H}$ of major diastereomer), $130.8\left(\mathrm{~d},{ }^{5} J_{\mathrm{C}-\mathrm{F}}=7.0 \mathrm{~Hz}, \mathrm{C}_{\mathrm{q}}\right.$, Ar of minor diastereomer $), 131.0\left(\mathrm{~d},{ }^{5} J_{\mathrm{C}-\mathrm{F}}=\right.$ $4.3 \mathrm{~Hz}, \mathrm{C}_{\mathrm{q}}$, Ar of major diastereomers), 138.4 (s, $\underline{\mathrm{C}}-\mathrm{OCH}_{3}$, Ar of major diastereomer), 138.5 (s, $\underline{\mathrm{C}}-\mathrm{OCH}_{3}$, Ar of minor diastereomer), 153.7 (s, $2 \times \underline{\mathrm{C}}-\mathrm{OCH}_{3}, \mathrm{Ar}$ of major diastereomer), 153.9 (s, $2 \times \underline{\mathrm{C}}-\mathrm{OCH}_{3}, \mathrm{Ar}$ of minor diastereomer), $155.1\left(\mathrm{~d},{ }^{3} J_{\mathrm{C}-\mathrm{F}}=9.0 \mathrm{~Hz}, \mathrm{C} 5\right.$ of major diastereomer), $155.8\left(\mathrm{~d},{ }^{3} J_{\mathrm{C}-\mathrm{F}}=8.4 \mathrm{~Hz}\right.$, C5 of minor diastereomer), $157.2\left(\mathrm{~d},{ }^{2} J_{\mathrm{C}-\mathrm{F}}=20.5 \mathrm{~Hz}, \mathrm{C} 2\right.$ of minor diastereomers), $157.5\left(\mathrm{~d},{ }^{2} J_{\mathrm{C}-\mathrm{F}}=\right.$ $19.6 \mathrm{~Hz}, \mathrm{C} 2$ of major diastereomer), $166.0\left(\mathrm{~d},{ }^{2} J_{\mathrm{C}-\mathrm{F}}=29.0 \mathrm{~Hz}, \mathrm{C}=\mathrm{O}\right.$ of minor diastereomer); $166.4(\mathrm{~d}$, ${ }^{2} J_{\mathrm{C}-\mathrm{F}}=27.5 \mathrm{~Hz}, \mathrm{C}=\mathrm{O}$ of minor diastereomer $)$ MS: $m / z=383[\mathrm{M}+1](100 \%)$.

\subsubsection{Methyl 2-ethyl-3-fluoro-6-(2-methoxyphenyl)-5-nitro-3,6-dihydropyridine-3-carboxylate (2e)}

Yellow oil. Yield $0.163 \mathrm{~g}$ (97\%). Mixture of diastereomers (the ratio is 50:50 according to the ${ }^{19} \mathrm{~F}$ and ${ }^{1} \mathrm{H}-\mathrm{NMR}$ spectra). ${ }^{1} \mathrm{H}-\mathrm{NMR}\left(\mathrm{CDCl}_{3}\right): \delta 1.08-1.14\left(\mathrm{~m}, 6 \mathrm{H}, 2 \times \mathrm{CH}_{2} \mathrm{CH}_{3}\right.$ of both diastereomers); 2.34-2.44 (m, 2H, $\left.\mathrm{CH}_{2} \mathrm{CH}_{3}\right), 2.51-2.64\left(\mathrm{~m}, 2 \mathrm{H}, \mathrm{CH}_{2} \mathrm{CH}_{3}\right), 3.84\left(\mathrm{~s}, 3 \mathrm{H}, \mathrm{OCH}_{3}\right), 3.87\left(\mathrm{~s}, 3 \mathrm{H}, \mathrm{COOCH}_{3}\right)$, $3.89\left(\mathrm{~s}, 3 \mathrm{H}, \mathrm{OCH}_{3}\right), \overline{3.95}\left(\mathrm{~s}, 3 \mathrm{H}, \mathrm{COOCH}_{3}\right), 6.20-6.25\left(\mathrm{dm}, 5 J_{\mathrm{H}-\mathrm{F}}=12.6 \mathrm{~Hz}, 1 \mathrm{H}, \mathrm{C} 6 \mathrm{H}\right), 6.71-6.77(\mathrm{dm}$, $\left.{ }^{5} J_{\mathrm{H}-\mathrm{F}}=17.0 \mathrm{~Hz}, 1 \mathrm{H}, \mathrm{C} 6 \mathrm{H}\right), 6.84-7.06(\mathrm{~m}, 6 \mathrm{H}, 6 \times \mathrm{CH}, \mathrm{Ar}), 7.00\left(\mathrm{dd},{ }^{3} J_{\mathrm{H}-\mathrm{F}}=6.5 \mathrm{~Hz},{ }^{4} J_{\mathrm{H}-\mathrm{H}}=1.6 \mathrm{~Hz}\right.$, $1 \mathrm{H}, \mathrm{C} 4 \mathrm{H}), 7.16\left(\mathrm{dd},{ }^{3} J_{\mathrm{H}-\mathrm{F}}=9.1 \mathrm{~Hz},{ }^{4} J_{\mathrm{H}-\mathrm{H}}=1.2 \mathrm{~Hz}, 1 \mathrm{H}, \mathrm{C} 4 \mathrm{H}\right), 7.26-7.30(\mathrm{~m}, 2 \mathrm{H}, 2 \times \mathrm{CH}$, Ar of both diastereomers). ${ }^{19} \mathrm{~F}-\mathrm{NMR}\left(\mathrm{CDCl}_{3}\right): \delta-140.5\left(\mathrm{dd},{ }^{5} J_{\mathrm{F}-\mathrm{H}}=17.0 \mathrm{~Hz},{ }^{3} J_{\mathrm{F}-\mathrm{H}}=9.1 \mathrm{~Hz}, 1 \mathrm{~F}, \mathrm{CF}\right),-145.1(\mathrm{dd}$, $\left.{ }^{5} J_{\mathrm{F}-\mathrm{H}}=12.6 \mathrm{~Hz},{ }^{3} J_{\mathrm{F}-\mathrm{H}}=6.5 \mathrm{~Hz}, 1 \mathrm{~F}, \mathrm{CF}\right) .{ }^{13} \mathrm{C}-\mathrm{NMR}\left(\mathrm{CDCl}_{3}\right): \delta 10.8\left(\mathrm{~s}, \mathrm{CH}_{2} \mathrm{CH}_{3}\right), 10.9\left(\mathrm{~s}, \mathrm{CH}_{2} \mathrm{CH}_{3}\right), 27.0$ $\left(\mathrm{s}, \underline{\mathrm{CH}_{2}} \mathrm{CH}_{3}\right), 27.1\left(\mathrm{~s}, \underline{\mathrm{CH}_{2}} \mathrm{CH}_{3}\right), 54.0\left(\mathrm{~s}, \mathrm{COOCH}_{3}\right), 54.1\left(\mathrm{~s}, \mathrm{COOCH}_{3}\right), 55.7\left(\mathrm{~s}, \mathrm{OCH}_{3}, \mathrm{Ar}\right), 55.9\left(\mathrm{~d},{ }^{4} J_{\mathrm{C}-\mathrm{F}}\right.$ $=2.6 \mathrm{~Hz}, \mathrm{C} 6 \mathrm{H}), 56.3\left(\mathrm{~s}, \mathrm{OCH}_{3}, \mathrm{Ar}\right), 56.9\left(\mathrm{~d},{ }^{4} J_{\mathrm{C}-\mathrm{F}}=3.4 \mathrm{~Hz}, \mathrm{C} 6 \mathrm{H}\right), 86.3\left(\mathrm{~d},{ }^{1} J_{\mathrm{C}-\mathrm{F}}=190.0 \mathrm{~Hz}, \mathrm{CF}\right), 86.4(\mathrm{~d}$, $\left.{ }^{1} J_{\mathrm{C}-\mathrm{F}}=190.3 \mathrm{~Hz}, \mathrm{CF}\right), 111.85$ (s, CH, Ar), 111.91 (s, CH, Ar), 120.7 (s, CH, Ar), 121.0 (d, ${ }^{2} J_{\mathrm{C}-\mathrm{F}}=25.4 \mathrm{~Hz}$, $\mathrm{C} 4 \mathrm{H}), 121.2(\mathrm{~s}, \mathrm{CH}, \mathrm{Ar}), 122.4\left(\mathrm{~d},{ }^{2} J_{\mathrm{C}-\mathrm{F}}=25.7 \mathrm{~Hz}, \mathrm{C} 4 \mathrm{H}\right), 124.3\left(\mathrm{~d},{ }^{5} J_{\mathrm{C}-\mathrm{F}}=6.3 \mathrm{~Hz}, \mathrm{C} \mathrm{q}, \mathrm{Ar}\right), 124.9\left(\mathrm{~d},{ }^{5} J_{\mathrm{C}-\mathrm{F}}\right.$ $\left.=3.9 \mathrm{~Hz}, \mathrm{C}_{\mathrm{q}}, \mathrm{Ph}\right), 127.8$ (s, CH, Ar), 129.2 (s, CH, Ar), 130.1 (s, CH, Ar), 130.2 (s, CH, Ar), 155.7 (d, ${ }^{3} J_{\mathrm{C}-\mathrm{F}}$ $=10.1 \mathrm{~Hz}, \mathrm{C} 5), 157.5\left(\mathrm{~d},{ }^{3} J_{\mathrm{C}-\mathrm{F}}=5.8 \mathrm{~Hz}, \mathrm{C} 5\right), 160.4\left(\mathrm{~d},{ }^{2} J_{\mathrm{C}-\mathrm{F}}=19.4 \mathrm{~Hz}, \mathrm{C} 2\right.$ of both diastereomers $), 166.2$ $\left(\mathrm{d},{ }^{2} J_{\mathrm{C}-\mathrm{F}}=29.1 \mathrm{~Hz}, \mathrm{C}=\mathrm{O}\right), 166.7\left(\mathrm{~d},{ }^{2} J_{\mathrm{C}-\mathrm{F}}=30.2 \mathrm{~Hz}, \mathrm{C}=\mathrm{O}\right) . \mathrm{MS}: \mathrm{m} / \mathrm{z}=337[\mathrm{M}+1](100 \%)$. 
3.2.6. Methyl 3-fluoro-2-methyl-5-nitro-6-(4-nitrophenyl)-3,6-dihydropyridine-3-carboxylate (2f)

Yellow oil. Yield $0.169 \mathrm{~g}(94 \%)$. Mixture of diastereomers (the ratio is $50: 50$ according to the ${ }^{19} \mathrm{~F}$ and ${ }^{1} \mathrm{H}-\mathrm{NMR}$ spectra). ${ }^{1} \mathrm{H}-\mathrm{NMR}\left(\mathrm{CDCl}_{3}\right): 2.22\left(\mathrm{dd},{ }^{4} J_{\mathrm{H}-\mathrm{F}}=1.9 \mathrm{~Hz},{ }^{4} J_{\mathrm{H}-\mathrm{H}}=0.9 \mathrm{~Hz}, 3 \mathrm{H}, \mathrm{CH}_{3}\right), 2.23-2.24$ $\left(\mathrm{dm},{ }^{4} J_{\mathrm{H}-\mathrm{F}}=1.6 \mathrm{~Hz}, 3 \mathrm{H}, \mathrm{CH}_{3}\right), 3.91\left(\mathrm{~s}, 3 \mathrm{H}, \mathrm{COOCH}_{3}\right), 3.92\left(\mathrm{~s}, 3 \mathrm{H}, \mathrm{COOCH}_{3}\right), 5.91-5.96\left(\mathrm{dm}^{5} J_{\mathrm{H}-\mathrm{F}}=\right.$ $11.4 \mathrm{~Hz}, 1 \mathrm{H}, \mathrm{C} 6 \mathrm{H}), 6.24-6.28\left(\mathrm{dm},{ }^{5} J_{\mathrm{H}-\mathrm{F}}=14.4 \mathrm{~Hz}, 1 \mathrm{H}, \mathrm{C} 6 \mathrm{H}\right), 7.21\left(\mathrm{dd},{ }^{3} J_{\mathrm{H}-\mathrm{F}}=5.7 \mathrm{~Hz},{ }^{4} J_{\mathrm{H}-\mathrm{H}}=1.3 \mathrm{~Hz}\right.$, $1 \mathrm{H}, \mathrm{C} 4 \mathrm{H}), 7.30\left(\mathrm{dd},{ }^{3} J_{\mathrm{H}-\mathrm{F}}=9.5 \mathrm{~Hz},{ }^{4} \mathrm{~J}_{\mathrm{H}-\mathrm{H}}=1.1 \mathrm{~Hz}, 1 \mathrm{H}, \mathrm{C} 4 \mathrm{H}\right), 7.41-7.44\left(\mathrm{dm},{ }^{3} J_{\mathrm{H}-\mathrm{H}}=8.7 \mathrm{~Hz}, 2 \mathrm{H}, 2 \times \mathrm{CH}\right.$, Ar), 7.54-7.58 (dm, $\left.{ }^{3} J_{\mathrm{H}-\mathrm{H}}=8.7 \mathrm{~Hz}, 2 \mathrm{H}, 2 \times \mathrm{CH}, \mathrm{Ar}\right), 8.20-8.25(\mathrm{~m}, 4 \mathrm{H}, 2 \times \mathrm{CH}$, Ar of both diastereomers). ${ }^{19} \mathrm{~F}-\mathrm{NMR}\left(\mathrm{CDCl}_{3}\right): \delta-141.6\left(\mathrm{dd},{ }^{5} J_{\mathrm{F}-\mathrm{H}}=14.4 \mathrm{~Hz},{ }^{3} J_{\mathrm{F}-\mathrm{H}}=9.5 \mathrm{~Hz}, 1 \mathrm{~F}, \mathrm{CF}\right),-143.0\left(\mathrm{dd},{ }^{5} J_{\mathrm{F}-\mathrm{H}}=11.4 \mathrm{~Hz}\right.$, $\left.{ }^{3} J_{\mathrm{F}-\mathrm{H}}=5.7 \mathrm{~Hz}, 1 \mathrm{~F}, \mathrm{CF}\right) .{ }^{13} \mathrm{C}-\mathrm{NMR}\left(\mathrm{CDCl}_{3}\right): \delta 20.9\left(\mathrm{~s}, \mathrm{CH}_{3}\right), 21.1\left(\mathrm{~s}, \mathrm{CH}_{3}\right), 54.5\left(\mathrm{~s}, 2 \times \mathrm{COOCH}_{3}\right.$ of both diastereomers), $61.1\left(\mathrm{~d},{ }^{4} J_{\mathrm{C}-\mathrm{F}}=3.3 \mathrm{~Hz}, \mathrm{C} 6 \mathrm{H}\right), 61.9\left(\mathrm{~d},{ }^{4} J_{\mathrm{C}-\mathrm{F}}=2.7 \mathrm{~Hz}, \mathrm{C} 6 \mathrm{H}\right), 85.8\left(\mathrm{~d},{ }^{1} J_{\mathrm{C}-\mathrm{F}}=190.2 \mathrm{~Hz}\right.$, CF), $86.2\left(\mathrm{~d},{ }^{1} J_{\mathrm{C}-\mathrm{F}}=194.1 \mathrm{~Hz}, \mathrm{CF}\right), 122.7\left(\mathrm{~d},{ }^{2} J_{\mathrm{C}-\mathrm{F}}=24.6 \mathrm{~Hz}, \mathrm{C} 4 \mathrm{H}\right), 123.9\left(\mathrm{~d},{ }^{2} J_{\mathrm{C}-\mathrm{F}}=26.4 \mathrm{~Hz}, \mathrm{C} 4 \mathrm{H}\right), 124.3$ (s, Ar), $124.5(\mathrm{~s}, \mathrm{Ar}), 129.2(\mathrm{~s}, \mathrm{Ar}), 129.4(\mathrm{~s}, \mathrm{Ar}), 142.86\left(\mathrm{~d},{ }^{5} J_{\mathrm{C}-\mathrm{F}}=6.9 \mathrm{~Hz}, \mathrm{C}_{\mathrm{q}}, \mathrm{Ar}\right), 142.92\left(\mathrm{~d},{ }^{5} J_{\mathrm{C}-\mathrm{F}}=4.0\right.$ $\left.\mathrm{Hz}, \mathrm{C}_{\mathrm{q}}, \mathrm{Ar}\right), 148.1\left(\mathrm{~s}, \mathrm{C}-\mathrm{NO}_{2}, \mathrm{Ar}\right), 148.2\left(\mathrm{~s}, \mathrm{C}-\mathrm{NO}_{2}, \mathrm{Ar}\right), 153.4\left(\mathrm{~d},{ }^{3} J_{\mathrm{C}-\mathrm{F}}=8.6 \mathrm{~Hz}, \mathrm{C} 5\right), 154.4\left(\mathrm{~d},{ }^{3} J_{\mathrm{C}-\mathrm{F}}=\right.$ $8.4 \mathrm{~Hz}, \mathrm{C} 5), 158.6\left(\mathrm{~d},{ }^{2} J_{\mathrm{C}-\mathrm{F}}=20.9 \mathrm{~Hz}, \mathrm{C} 2\right), 159.0\left(\mathrm{~d},{ }^{2} J_{\mathrm{C}-\mathrm{F}}=20.0 \mathrm{~Hz}, \mathrm{C}_{2}\right), 165.6\left(\mathrm{~d},{ }^{2} J_{\mathrm{C}-\mathrm{F}}=28.6 \mathrm{~Hz}, \mathrm{C}=\mathrm{O}\right.$ of both diastereomers). MS: $m / z=338[\mathrm{M}+1](100 \%)$.

\subsubsection{Methyl 3-fluoro-6-(3-fluorophenyl)-2-methyl-5-nitro-3,6-dihydropyridine-3-carboxylate (2g)}

Yellow oil. Yield $0.136 \mathrm{~g}(88 \%)$. Mixture of diastereomers (the ratio is $50: 50$ according to the ${ }^{19} \mathrm{~F}$ and ${ }^{1} \mathrm{H}-\mathrm{NMR}$ spectra). ${ }^{1} \mathrm{H}-\mathrm{NMR}\left(\mathrm{CDCl}_{3}\right): \delta 2.20-2.21\left(\mathrm{dm},{ }^{4} \mathrm{~J}_{\mathrm{H}-\mathrm{F}}=1.8 \mathrm{~Hz}, 3 \mathrm{H}, \mathrm{CH}_{3}\right), 2.22-2.23$ $\left(\mathrm{dm},{ }^{4} J_{\mathrm{H}-\mathrm{F}}=1.5 \mathrm{~Hz}, 3 \mathrm{H}, \mathrm{CH}_{3}\right), 3.90\left(\mathrm{~s}, 3 \mathrm{H}, \mathrm{COOCH}_{3}\right), 3.91\left(\mathrm{~s}, 3 \mathrm{H}, \mathrm{COOCH}_{3}\right), 5.82-5.87\left(\mathrm{dm}^{5} J_{\mathrm{H}-\mathrm{F}}=\right.$ $11.8 \mathrm{~Hz}, 1 \mathrm{H}, \mathrm{C} 6 \mathrm{H}), 6.14-6.18\left(\mathrm{dm},{ }^{5} J_{\mathrm{H}-\mathrm{F}}=14.9 \mathrm{~Hz}, 1 \mathrm{H}, \mathrm{C} 6 \mathrm{H}\right), 6.93-6.96\left(\mathrm{dm},{ }^{3} J_{\mathrm{H}-\mathrm{F}}=9.5 \mathrm{~Hz}, 1 \mathrm{H}, \mathrm{CH}\right.$, Ar), 7.00-7.06 (m, 4H, CH, Ar of both diastereomers), $7.12\left(\mathrm{dd},{ }^{3} J_{\mathrm{H}-\mathrm{F}}=5.6 \mathrm{~Hz},{ }^{4} J_{\mathrm{H}-\mathrm{H}}=1.2 \mathrm{~Hz}, 1 \mathrm{H}\right.$, $\mathrm{C} 4 \mathrm{H}), 7.17-7.20\left(\mathrm{dm},{ }^{3} J_{\mathrm{H}-\mathrm{F}}=7.7 \mathrm{~Hz}, 1 \mathrm{H}, \mathrm{CH}, \mathrm{Ar}\right), 7.22\left(\mathrm{dd},{ }^{3} J_{\mathrm{H}-\mathrm{F}}=9.4 \mathrm{~Hz},{ }^{4} J_{\mathrm{H}-\mathrm{H}}=1.1 \mathrm{~Hz}, 1 \mathrm{H}, \mathrm{C} 4 \mathrm{H}\right)$, 7.31-7.37 (m, 2H, CH, Ar of both diastereomers). ${ }^{19} \mathrm{~F}-\mathrm{NMR}\left(\mathrm{CDCl}_{3}\right): \delta-111.46-(-111.52)(\mathrm{m}, 1 \mathrm{~F}, \mathrm{CF}$, Ar), $-111.73-(-111.79)(\mathrm{m}, 1 \mathrm{~F}, \mathrm{CF}, \mathrm{Ar}),-140.7\left(\mathrm{dd},{ }^{5} \mathrm{~J}_{\mathrm{F}-\mathrm{H}}=14.9 \mathrm{~Hz},{ }^{3} J_{\mathrm{F}-\mathrm{H}}=9.5 \mathrm{~Hz}, 1 \mathrm{~F}, \mathrm{CF}\right),-142.8$ $\left(\mathrm{dd},{ }^{5} J_{\mathrm{F}-\mathrm{H}}=11.8 \mathrm{~Hz},{ }^{3} J_{\mathrm{F}-\mathrm{H}}=5.6 \mathrm{~Hz}, 1 \mathrm{~F}, \mathrm{CF}\right) .{ }^{13} \mathrm{C}-\mathrm{NMR}\left(\mathrm{CDCl}_{3}\right): \delta 20.8\left(\mathrm{~s}, \mathrm{CH}_{3}\right), 21.0\left(\mathrm{~s}, \mathrm{CH}_{3}\right), 54.3$ $\left(\mathrm{s}, \mathrm{COOCH}_{3}\right), 54.4\left(\mathrm{~s}, \mathrm{COOCH}_{3}\right), 61.4\left(\mathrm{dd},{ }^{4} J_{\mathrm{C}-\mathrm{F}}=3.2 \mathrm{~Hz},{ }^{4} J_{\mathrm{C}-\mathrm{F}}=2.0 \mathrm{~Hz}, \mathrm{C} 6 \mathrm{H}\right), 62.0\left(\mathrm{t},{ }^{4} J_{\mathrm{C}-\mathrm{F}}=2.2 \mathrm{~Hz}\right.$, $\mathrm{C} 6 \mathrm{H}), 84.7\left(\mathrm{~d},{ }^{1} J_{\mathrm{C}-\mathrm{F}}=190.7 \mathrm{~Hz}, \mathrm{CF}\right), 86.0\left(\mathrm{~d},{ }^{1} J_{\mathrm{C}-\mathrm{F}}=191.9 \mathrm{~Hz}, \mathrm{CF}\right), 115.2\left(\mathrm{~d},{ }^{2} J_{\mathrm{C}-\mathrm{F}}=23.2 \mathrm{~Hz}, \mathrm{CH}, \mathrm{Ar}\right)$, $115.3\left(\mathrm{~d},{ }^{2} J_{\mathrm{C}-\mathrm{F}}=22.4 \mathrm{~Hz}, \mathrm{CH}, \mathrm{Ar}\right), 115.9\left(\mathrm{~d},{ }^{2} J_{\mathrm{C}-\mathrm{F}}=21.1 \mathrm{~Hz}, \mathrm{CH}, \mathrm{Ar}\right), 116.1\left(\mathrm{~d},{ }^{2} J_{\mathrm{C}-\mathrm{F}}=21.1 \mathrm{~Hz}, \mathrm{CH}\right.$, Ar), $121.7\left(\mathrm{~d},{ }^{2} J_{\mathrm{C}-\mathrm{F}}=24.2 \mathrm{~Hz}, \mathrm{C} 4 \mathrm{H}\right), 122.9\left(\mathrm{~d},{ }^{2} J_{\mathrm{C}-\mathrm{F}}=26.4 \mathrm{~Hz}, \mathrm{C} 4 \mathrm{H}\right), 123.8\left(\mathrm{~d},{ }^{4} J_{\mathrm{C}-\mathrm{F}}=3.0 \mathrm{~Hz}, \mathrm{CH}, \mathrm{Ar}\right)$, $124.3\left(\mathrm{~d},{ }^{4} J_{\mathrm{C}-\mathrm{F}}=3.1 \mathrm{~Hz}, \mathrm{CH}, \mathrm{Ar}\right), 130.7\left(\mathrm{~d},{ }^{3} J_{\mathrm{C}-\mathrm{F}}=8.5 \mathrm{~Hz}, \mathrm{CH}, \mathrm{Ar}\right), 130.9\left(\mathrm{~d},{ }^{3} J_{\mathrm{C}-\mathrm{F}}=8.2 \mathrm{~Hz}, \mathrm{CH}, \mathrm{Ar}\right)$, 137.91-138.06 (dm, $\left.{ }^{5} J_{\mathrm{C}-\mathrm{F}}=7.0 \mathrm{~Hz}, \mathrm{C}_{\mathrm{q}}, \mathrm{Ar}\right), 138.2\left(\mathrm{dd},{ }^{5} J_{\mathrm{C}-\mathrm{F}}=4.1 \mathrm{~Hz},{ }^{3} J_{\mathrm{C}-\mathrm{F}}=7.4 \mathrm{~Hz}, \mathrm{C}_{\mathrm{q}}, \mathrm{Ar}\right), 154.2(\mathrm{~d}$, $\left.{ }^{3} J_{\mathrm{C}-\mathrm{F}}=9.0 \mathrm{~Hz}, \mathrm{C} 5\right), 155.2\left(\mathrm{~d},{ }^{3} J_{\mathrm{C}-\mathrm{F}}=8.5 \mathrm{~Hz}, \mathrm{C} 5\right), 157.7\left(\mathrm{~d},{ }^{2} J_{\mathrm{C}-\mathrm{F}}=20.7 \mathrm{~Hz}, \mathrm{C} 2\right), 158.1\left(\mathrm{~d},{ }^{2} J_{\mathrm{C}-\mathrm{F}}=19.8 \mathrm{~Hz}\right.$, C2), $163.0\left(\mathrm{~d},{ }^{1} J_{\mathrm{C}-\mathrm{F}}=246.2 \mathrm{~Hz}, \mathrm{CF}, \mathrm{Ar}\right), 163.1\left(\mathrm{~d},{ }^{1} J_{\mathrm{C}-\mathrm{F}}=247.6 \mathrm{~Hz}, \mathrm{CF}, \mathrm{Ar}\right), 165.5\left(\mathrm{~d},{ }^{2} J_{\mathrm{C}-\mathrm{F}}=29.0 \mathrm{~Hz}\right.$, $\mathrm{C}=\mathrm{O}), 165.9\left(\mathrm{~d},{ }^{2} \mathrm{~J}_{\mathrm{C}-\mathrm{F}}=29.6 \mathrm{~Hz}, \mathrm{C}=\mathrm{O}\right)$. MS: $\mathrm{m} / \mathrm{z}=311[\mathrm{M}+1](100 \%)$.

3.2.8. Methyl 6-(1,3-diphenyl-1H-pyrazol-4-yl)-3-fluoro-2-methyl-5-nitro-3,6-dihydropyridine3-carboxylate (2h)

Yellow brown oil. Yield $0.150 \mathrm{~g}(89 \%)$. Mixture of diastereomers (the ratio is 10:90 according to the ${ }^{19} \mathrm{~F}$ and ${ }^{1} \mathrm{H}-\mathrm{NMR}$ spectra). ${ }^{1} \mathrm{H}-\mathrm{NMR}\left(\mathrm{CDCl}_{3}\right): \delta 2.18-2.20\left(\mathrm{dm},{ }^{4} J_{\mathrm{H}-\mathrm{F}}=1.8 \mathrm{~Hz}, 3 \mathrm{H}, \mathrm{CH}_{3}\right)$, $2.25-2.26\left(\mathrm{dm},{ }^{4} J_{\mathrm{H}-\mathrm{F}}=1.5 \mathrm{~Hz}, 3 \mathrm{H}, \mathrm{CH}_{3}\right), 3.97\left(\mathrm{~s}, 3 \mathrm{H}, \mathrm{COOCH}_{3}\right), 3.98\left(\mathrm{~s}, 3 \mathrm{H}, \mathrm{COOCH}_{3}\right), 6.03-6.07$ $\left(\mathrm{dm},{ }^{5} J_{\mathrm{H}-\mathrm{F}}=11.9 \mathrm{~Hz}, 1 \mathrm{H}, \mathrm{C} 6 \mathrm{H}\right.$ of minor diastereomer $), 6.27-6.32\left(\mathrm{dm},{ }^{5} J_{\mathrm{H}-\mathrm{F}}=14.0 \mathrm{~Hz}, 1 \mathrm{H}, \mathrm{C} 6 \mathrm{H}\right.$ of major diastereomer), $7.02\left(\mathrm{dd},{ }^{3} J_{\mathrm{H}-\mathrm{F}}=5.8 \mathrm{~Hz},{ }^{4} J_{\mathrm{H}-\mathrm{H}}=1.5 \mathrm{~Hz}, 1 \mathrm{H}, \mathrm{C} 4 \mathrm{H}\right), 7.19\left(\mathrm{dd},{ }^{3} J_{\mathrm{H}-\mathrm{F}}=9.5 \mathrm{~Hz}\right.$, $\left.{ }^{4} J_{\mathrm{H}-\mathrm{H}}=1.1 \mathrm{~Hz}, 1 \mathrm{H}, \mathrm{C} 4 \mathrm{H}\right), 7.42-7.48(\mathrm{~m}, 8 \mathrm{H}, \mathrm{CH}, \mathrm{Ph}$ of both diastereomers), 7.50-7.55 (m, 4H, CH, Ph of both diastereomers), 7.66-7.69 (m, $4 \mathrm{H}, \mathrm{CH}$, Ph of both diastereomers), 7.87 (s, 2H, CH, pyrazolyl of both diastereomers), 8.01-8.04 (m, 4H, CH, Ph of both diastereomers). ${ }^{19} \mathrm{~F}-\mathrm{NMR}\left(\mathrm{CDCl}_{3}\right): \delta-142.6$ $\left(\mathrm{dd},{ }^{5} J_{\mathrm{F}-\mathrm{H}}=14.0 \mathrm{~Hz},{ }^{3} J_{\mathrm{F}-\mathrm{H}}=9.5 \mathrm{~Hz}, 1 \mathrm{~F}, \mathrm{CF}\right.$ of major diastereomer $),-144.2\left(\mathrm{dd},{ }^{5} J_{\mathrm{F}-\mathrm{H}}=11.9 \mathrm{~Hz},{ }^{3} J_{\mathrm{F}-\mathrm{H}}=\right.$ $5.8 \mathrm{~Hz}, 1 \mathrm{~F}, \mathrm{CF}$ of minor diastereomer). ${ }^{13} \mathrm{C}-\mathrm{NMR}\left(\mathrm{CDCl}_{3}\right): \delta 20.8$ (s, $\mathrm{CH}_{3}$ of major diastereomer), 21.1 (s, $\mathrm{CH}_{3}$ of minor diastereomer), $53.7\left(\mathrm{~d},{ }^{4} J_{\mathrm{C}-\mathrm{F}}=2.4 \mathrm{~Hz}, \mathrm{C} 6 \mathrm{H}\right.$ of major diastereomer), $54.3\left(\mathrm{~s}, \mathrm{COOCH}_{3}\right.$ of minor diastereomer), 54.5 (s, $\mathrm{COOCH}_{3}$ of major diastereomer), $86.6\left(\mathrm{~d},{ }^{1} J_{\mathrm{C}-\mathrm{F}}=193.8 \mathrm{~Hz}, \mathrm{CF}\right.$ of 
major diastereomer), $117.2\left(\mathrm{~d},{ }^{5} J_{\mathrm{C}-\mathrm{F}}=4.1 \mathrm{~Hz}\right.$, pyrazolyl of major diastereomer), 119.2 (s, Ph, of major diastereomer) $122.1\left(\mathrm{~d},{ }^{2} J_{\mathrm{C}-\mathrm{F}}=26.3 \mathrm{~Hz}, \mathrm{C} 4 \mathrm{H}\right.$ of major diastereomer), 126.9 (s, Ph of both diastereomers), 128.7 (s, CH, pyrazolyl of both diastereomers), 128.8 (s, Ph of both diastereomers), 128.9 (s, Ph of both diastereomers), 129.6 (s, Ph of both diastereomers), 132.6 (s, $\mathrm{C}_{\mathrm{q}}, \mathrm{Ph}$ of both diastereomers), 132.6 (s, $\mathrm{C}_{\mathrm{q}}$, Ph of both diastereomers), 139.9 (s, $\mathrm{C}_{\mathrm{q}}$, Ph of both diastereomers), 153.0 (s, C-Ph, pyrazolyl of both diastereomers), $154.8\left(\mathrm{~d},{ }^{3} J_{\mathrm{C}-\mathrm{F}}=8.7 \mathrm{~Hz}, \mathrm{C}_{5}\right.$ of major diastereomer $), 157.1\left(\mathrm{~d},{ }^{2} J_{\mathrm{C}-\mathrm{F}}=20.2 \mathrm{~Hz}, \mathrm{C} 2\right.$ of major diastereomer), $166.2\left(\mathrm{~d},{ }^{2} J_{\mathrm{C}-\mathrm{F}}=29.6 \mathrm{~Hz}, \mathrm{C}=\mathrm{O}\right.$ of major diastereomer $)$ MS: $m / z=338[\mathrm{M}+1](100 \%)$.

\subsubsection{Diethyl 5-fluoro-4,6-dimethyl-2-phenyl-2,5-dihydropyridine-3,5-dicarboxylate (2k)}

Pale yellow oil. Yield $0.142 \mathrm{~g}(82 \%)$. Mixture of diastereomers (the ratio is $15: 85$ according to the ${ }^{19} \mathrm{~F}$ and ${ }^{1} \mathrm{H}-\mathrm{NMR}$ spectra). ${ }^{1} \mathrm{H}-\mathrm{NMR}\left(\mathrm{CDCl}_{3}\right): \delta 0.89\left(\mathrm{t},{ }^{3} J_{\mathrm{H}-\mathrm{H}}=7.4 \mathrm{~Hz}, 3 \mathrm{H}, \mathrm{COOCH}_{2} \mathrm{CH}_{3}\right.$ of minor diastereomer), $1.01\left(\mathrm{t},{ }^{3} \mathrm{~J}_{\mathrm{H}-\mathrm{H}}=7.4 \mathrm{~Hz}, 3 \mathrm{H}, \mathrm{COOCH}_{2} \mathrm{CH}_{3}\right.$ of major diastereomer), $1.13\left(\mathrm{t},{ }^{3} J_{\mathrm{H}-\mathrm{H}}=6.9 \mathrm{~Hz}, 3 \mathrm{H}\right.$, $\mathrm{FCOOCH}_{2} \underline{\mathrm{CH}}_{3}$ of minor diastereomer), $1.23\left(\mathrm{t},{ }^{3} \mathrm{~J}_{\mathrm{H}-\mathrm{H}}=7.4 \mathrm{~Hz}, 3 \mathrm{H}, \mathrm{FCOOCH} \mathrm{CH}_{3}\right.$ of major diastereomer), $1.94\left(\mathrm{~d},{ }^{4} J_{\mathrm{H}-\mathrm{F}}=2.1 \mathrm{~Hz}, 3 \mathrm{H}, \mathrm{CH}_{3}\right.$ of minor diastereomer), $2.02\left(\mathrm{~d},{ }^{4} \mathrm{~J}_{\mathrm{H}-\mathrm{F}}=1.9 \mathrm{~Hz}, 3 \mathrm{H}, \mathrm{CH}_{3}\right.$ of major diastereomer), $2.07\left(\mathrm{dd},{ }^{4} J_{\mathrm{H}-\mathrm{F}}=1.8 \mathrm{~Hz},{ }^{5} J_{\mathrm{H}-\mathrm{H}}=1.4 \mathrm{~Hz}, 3 \mathrm{H}, \mathrm{CH}_{3} \mathrm{C}=\mathrm{N}\right.$ of major diastereomer), 2.09 (dd, ${ }^{4} J_{\mathrm{H}-\mathrm{F}}=2.4 \mathrm{~Hz},{ }^{5} J_{\mathrm{H}-\mathrm{H}}=1.9 \mathrm{~Hz}, 3 \mathrm{H}, \mathrm{CH}_{3} \mathrm{C}=\mathrm{N}$ of minor diastereomer $), 3.84-3.93\left(\mathrm{~m}, 4 \mathrm{H}, 2 \times \mathrm{COOC}_{2} \mathrm{CH}_{3}\right.$ of both diastereomers), 4.07-4.16 (m, $4 \mathrm{H}, 2 \times \mathrm{COOCH}_{2} \mathrm{CH}_{3}$ of both diastereomers), 5.24-5.30 (dm, ${ }^{5} J_{\mathrm{H}-\mathrm{F}}=$ $12.0 \mathrm{~Hz}, 1 \mathrm{H}, \mathrm{C} 6 \mathrm{H}$ of minor diastereomer), $5.57-5.62\left(\mathrm{dm},{ }^{5} J_{\mathrm{H}-\mathrm{F}}=15.5 \mathrm{~Hz}, 1 \mathrm{H}, \mathrm{C} 6 \mathrm{H}\right.$ of major diastereomer), 7.11-7.34 (m, 10H, CH, Ph of both diastereomers). ${ }^{19} \mathrm{~F}-\mathrm{NMR}\left(\mathrm{CDCl}_{3}\right): \delta-145.9\left(\mathrm{~d},{ }^{5} \mathrm{~J}_{\mathrm{F}-\mathrm{H}}=15.6 \mathrm{~Hz}, 1 \mathrm{~F}, \mathrm{CF}\right.$ of major diastereomer), $-150.4\left(\mathrm{~d},{ }^{5} \mathrm{~J}_{\mathrm{F}-\mathrm{H}}=12.2 \mathrm{~Hz}, 1 \mathrm{~F}, \mathrm{CF}\right.$ of minor diastereomer $) .{ }^{13} \mathrm{C}-\mathrm{NMR}\left(\mathrm{CDCl}_{3}\right): \delta$ $13.5\left(\mathrm{~d},{ }^{3} \mathrm{~J}_{\mathrm{C}-\mathrm{H}}=4.5 \mathrm{~Hz}, \mathrm{CH}_{3}\right.$ of both diastereomers), 14.0 (s, $\mathrm{COOCH}_{2} \underline{\mathrm{CH}}_{3}$ of both diastereomers), 14.1 (s, $\mathrm{COOCH}_{2} \underline{\mathrm{CH}}_{3}$ of both diastereomers), 21.2 (s, $\underline{\mathrm{CH}}_{3} \mathrm{C}=\mathrm{N}$ of both diastereomers), 61.1 (s, $\mathrm{COOC}_{2} \underline{\mathrm{CH}}_{3}$ of both diastereomers), 63.2 (s, $\mathrm{COOC} \underline{H}_{2} \mathrm{CH}_{3}$ of both diastereomers), 64.5 (d, ${ }^{4} J_{\mathrm{C}-\mathrm{F}}=2.5 \mathrm{~Hz}, \mathrm{C} 6 \mathrm{H}$ of minor diastereomer), $65.3\left(\mathrm{~d},{ }^{4} J_{\mathrm{C}-\mathrm{F}}=1.8 \mathrm{~Hz}, \mathrm{C} 6 \mathrm{H}\right.$ of major diastereomer), $84.65\left(\mathrm{~d},{ }^{1} J_{\mathrm{C}-\mathrm{F}}=183.8 \mathrm{~Hz}, \mathrm{CF}\right.$ of major diastereomer), 127.8 (s, CH, Ph), 128.0 (s, CH, Ph), 128.3 (s, 2×CH, Ph), 128.4 (s, 2×CH, Ph), 128.5 (s, $2 \times \mathrm{CH}$, $\mathrm{Ph}), 128.6(\mathrm{~s}, 2 \times \mathrm{CH}, \mathrm{Ph}), 130.7\left(\mathrm{~d},{ }^{2} J_{\mathrm{C}-\mathrm{F}}=22.1 \mathrm{~Hz}, \mathrm{C} 4\right.$ of minor diastereomer), $132.0\left(\mathrm{~d},{ }^{2} J_{\mathrm{C}-\mathrm{F}}=21.6 \mathrm{~Hz}, \mathrm{C} 4\right.$ of major diastereomer), $133.8\left(\mathrm{~d},{ }^{5} J_{\mathrm{C}-\mathrm{F}}=4.8 \mathrm{~Hz}, \mathrm{C}_{\mathrm{q}}\right.$, Ph of major diastereomer), $134.2\left(\mathrm{~d},{ }^{5} J_{\mathrm{C}-\mathrm{F}}=5.1 \mathrm{~Hz}, \mathrm{C}_{\mathrm{q}}\right.$, Ph of minor diastereomer), $138.8\left(\mathrm{~d},{ }^{3} J_{\mathrm{C}-\mathrm{F}}=4.8 \mathrm{~Hz}, \mathrm{C} 5\right.$ of major diastereomer), $139.2\left(\mathrm{~d},{ }^{3} J_{\mathrm{C}-\mathrm{F}}=5.4 \mathrm{~Hz}, \mathrm{C} 5\right.$ of minor diastereomer), $157.4\left(\mathrm{~d},{ }^{2} J_{\mathrm{C}-\mathrm{F}}=22.7 \mathrm{~Hz}, \mathrm{C} 2\right.$ of major diastereomer), $158.5\left(\mathrm{~d},{ }^{2} J_{\mathrm{C}-\mathrm{F}}=20.4 \mathrm{~Hz}, \mathrm{C} 2\right.$ of minor diastereomer), 165.9 (s, C=O), 166.2 (s, C=O), $166.5\left(\mathrm{~d},{ }^{2} \mathrm{~J}_{\mathrm{C}-\mathrm{F}}=29.7 \mathrm{~Hz}, \mathrm{C}=\mathrm{O}, \mathrm{CH}_{3} \mathrm{CH}_{2} \underline{\mathrm{COOCF}}\right.$ ). MS: $m / z=348[\mathrm{M}+1](100 \%)$.

\subsection{General Procedure for the Synthesis of Pyridines $3 a-k$}

A deuterochloroform solution (3 $\mathrm{mL})$ of 3-fluoro-3,6-dihydropyridines $\mathbf{2 a - k}(0.3 \mathrm{mmol})$ was maintained for 2 days in the case of compounds $\mathbf{2} \mathbf{c}, \mathbf{d}, \mathbf{e}, \mathbf{h}, \mathbf{k}$ and for 4 days in the case of compounds $\mathbf{2} \mathbf{a}, \mathbf{b}, \mathbf{f}, \mathbf{g}$ at room temperature, after which the solvent was evaporated in vacuo. Pyridines $\mathbf{3 a}-\mathbf{k}$ were isolated by column chromatography in 72-91\% yields.

\subsubsection{Methyl 2-methyl-5-nitro-6-phenylnicotinate (3a)}

White powder. Yield $0.074 \mathrm{~g}(91 \%) . \mathrm{Mp} 93-94{ }^{\circ} \mathrm{C}$ (from ethanol). $\mathrm{R}_{\mathrm{f}}: 0.54$ (petroleum ether - ethyl acetate 4:1). Anal. calcd for $\mathrm{C}_{14} \mathrm{H}_{12} \mathrm{~N}_{2} \mathrm{O}_{4}$ : C, 61.76; $\mathrm{H}, 4.44 ; \mathrm{N}, 10.29$; found: $\mathrm{C}, 61.85 ; \mathrm{H}, 4.55 ; \mathrm{N}, 10.16$. ${ }^{1} \mathrm{H}-\mathrm{NMR}\left(\mathrm{CDCl}_{3}\right): \delta 2.98\left(\mathrm{~s}, 3 \mathrm{H}, \mathrm{CH}_{3}\right), 3.98\left(\mathrm{~s}, 3 \mathrm{H}, \mathrm{COOCH}_{3}\right), 7.47-7.49(\mathrm{~m}, 3 \mathrm{H}, 3 \times \mathrm{CH}, \mathrm{Ph}), 7.59-7.61$ $(\mathrm{m}, 2 \mathrm{H}, 2 \times \mathrm{CH}, \mathrm{Ph}), 8.69(\mathrm{~s}, 1 \mathrm{H}, \mathrm{C} 4 \mathrm{H}) .{ }^{13} \mathrm{C}-\mathrm{NMR}\left(\mathrm{CDCl}_{3}\right): \delta 25.4\left(\mathrm{~s}, \mathrm{CH}_{3}\right), 53.0\left(\mathrm{~s}, \mathrm{COOCH}_{3}\right), 123.8(\mathrm{~s}$, C3), 128.5 (s, CH, Ph), 129.0 (s, CH, Ph), 130.5 (s, CH, Ph), 135.1 (s, C q Ph), 135.9 (s, C4H), 143.9 (s, C5), 154.5 (s, C6), 163.5 (s, C2), 165.0 (s, C=O). MS: $m / z=273[\mathrm{M}+1](100 \%)$.

\subsubsection{Methyl 6-([1,1'-biphenyl]-4-yl)-2-methyl-5-nitronicotinate (3b)}

Colorless viscous oil. Yield $0.089 \mathrm{~g}(85 \%) . \mathrm{R}_{\mathrm{f}}$ : 0.50 (petroleum ether - ethyl acetate 4:1). Anal. calcd for $\mathrm{C}_{20} \mathrm{H}_{16} \mathrm{~N}_{2} \mathrm{O}_{4}$ : C, 68.96; $\mathrm{H}, 4.63 ; \mathrm{N}, 8.04$; found: $\mathrm{C}, 69.02 ; \mathrm{H}, 4.71 ; \mathrm{N}, 7.96 .{ }^{1} \mathrm{H}-\mathrm{NMR}\left(\mathrm{CDCl}_{3}\right)$ : 
$\delta 3.00\left(\mathrm{~s}, 3 \mathrm{H}, \mathrm{CH}_{3}\right), 4.00\left(\mathrm{~s}, 3 \mathrm{H}, \mathrm{COOCH}_{3}\right), 7.36-7.50(\mathrm{~m}, 3 \mathrm{H}, \mathrm{Ar}), 7.62-7.65(\mathrm{~m}, 2 \mathrm{H}, \mathrm{Ar}), 7.70(\mathrm{~s}, 4 \mathrm{H}$, Ar), $8.71(\mathrm{~s}, 1 \mathrm{H}, \mathrm{C} 4 \mathrm{H})$. MS: $m / z=349[\mathrm{M}+1](100 \%)$.

\subsubsection{Methyl 6-(2-methoxyphenyl)-2-methyl-5-nitronicotinate (3c)}

Colorless viscous oil. Yield $0.065 \mathrm{~g}(72 \%) . \mathrm{R}_{\mathrm{f}}$ : 0.63 (petroleum ether-ethyl acetate 4:1). ${ }^{1} \mathrm{H}-\mathrm{NMR}$ $\left(\mathrm{CDCl}_{3}\right): \delta 2.98\left(\mathrm{~s}, 3 \mathrm{H}, \mathrm{CH}_{3}\right), 3.71\left(\mathrm{~s}, 3 \mathrm{H}, \mathrm{OCH}_{3}\right), 3.98\left(\mathrm{~s}, 3 \mathrm{H}, \mathrm{COOCH}_{3}\right), 6.91\left(\mathrm{~d},{ }^{3} J_{\mathrm{H}-\mathrm{H}}=8.4 \mathrm{~Hz}, 1 \mathrm{H}, \mathrm{CH}\right.$, $\mathrm{Ar}), 7.16\left(\mathrm{td},{ }^{3} J_{\mathrm{H}-\mathrm{H}}=7.6 \mathrm{~Hz},{ }^{4} J_{\mathrm{H}-\mathrm{H}}=1.0 \mathrm{~Hz}, 1 \mathrm{H}, \mathrm{CH}, \mathrm{Ar}\right), 7.46\left(\mathrm{ddd},{ }^{3} J_{\mathrm{H}-\mathrm{H}}=7.6 \mathrm{~Hz},{ }^{3} J_{\mathrm{H}-\mathrm{H}}=8.4 \mathrm{~Hz}\right.$, $\left.{ }^{4} J_{\mathrm{H}-\mathrm{H}}=1.7 \mathrm{~Hz}, 1 \mathrm{H}, \mathrm{CH}, \mathrm{Ar}\right), 7.73\left(\mathrm{dd},{ }^{3} J_{\mathrm{H}-\mathrm{H}}=7.6 \mathrm{~Hz},{ }^{4} J_{\mathrm{H}-\mathrm{H}}=1.7 \mathrm{~Hz}, 1 \mathrm{H}, \mathrm{CH}, \mathrm{Ar}\right), 8.74(\mathrm{~s}, 1 \mathrm{H}, \mathrm{C} 4 \mathrm{H})$. HRMS $\left(\right.$ ESI $^{+}$): Calcd for $\mathrm{C}_{15} \mathrm{H}_{14} \mathrm{~N}_{2} \mathrm{O}_{5}[\mathrm{M}+\mathrm{H}]$ : 303.0981; found 303.0985.

\subsubsection{Methyl 2-methyl-5-nitro-6-(3,4,5-trimethoxyphenyl)nicotinate (3d)}

Red brown powder. Yield $0.091 \mathrm{~g}(84 \%)$. Mp $172-173^{\circ} \mathrm{C}$ (from ethanol). $\mathrm{R}_{\mathrm{f}}$ : 0.29 (petroleum ether - ethyl acetate 4:1). IR $v_{\max }$ (Film) 3006, 2945, 2840, 1731, 1592, 1554, 1455, 1424, 1334. ${ }^{1} \mathrm{H}-\mathrm{NMR}$ $\left(\mathrm{CDCl}_{3}\right): \delta 2.97\left(\mathrm{~s}, 3 \mathrm{H}, \mathrm{CH}_{3}\right), 3.89\left(\mathrm{~s}, 6 \mathrm{H}, 2 \times \mathrm{OCH}_{3}, \mathrm{Ar}\right), 3.90\left(\mathrm{~s}, 3 \mathrm{H}, \mathrm{OCH}_{3}, \mathrm{Ar}\right), 3.98\left(\mathrm{~s}, 3 \mathrm{H}, \mathrm{COOCH}_{3}\right)$, $6.82(\mathrm{~s}, 2 \mathrm{H}, 2 \times \mathrm{CH}, \mathrm{Ar}), 8.63(\mathrm{~s}, 1 \mathrm{H}, \mathrm{C} 4 \mathrm{H}) .{ }^{13} \mathrm{C}-\mathrm{NMR}\left(\mathrm{CDCl}_{3}\right): \delta 25.4\left(\mathrm{~s}, \mathrm{CH}_{3}\right), 53.0\left(\mathrm{~s}, \mathrm{COOCH}_{3}\right), 56.4(\mathrm{~s}$, $\left.2 \times \mathrm{OCH}_{3}, \mathrm{Ar}\right), 61.1\left(\mathrm{~s}, \mathrm{OCH}_{3}, \mathrm{Ar}\right), 105.8(\mathrm{~s}, 2 \times \mathrm{CH}, \mathrm{Ar}), 123.7(\mathrm{~s}, \mathrm{C} 3), 130.8\left(\mathrm{~s}, \mathrm{C}_{\mathrm{q}}, \mathrm{Ar}\right), 134.9(\mathrm{~s}, \mathrm{CH})$, 140.3 (s, $\left.\underline{\mathrm{C}}-\mathrm{OCH}_{3}, \mathrm{Ar}\right), 144.0$ (s, C5), 153.7 (s, $2 \times \mathrm{OCH}_{3}, \mathrm{Ar}$ ), 153.8 (s, C6), 163.3 (s, C2), 164.9 (s, C=O). HRMS (ESI ${ }^{+}$): Calcd for $\mathrm{C}_{17} \mathrm{H}_{18} \mathrm{~N}_{2} \mathrm{O}_{7}[\mathrm{M}+\mathrm{H}]$ : 363.1192; found 363.1201.

\subsubsection{Methyl 2-ethyl-6-(2-methoxyphenyl)-5-nitronicotinate (3e)}

Pale yellow oil. Yield $0.078 \mathrm{~g}(82 \%)$. $\mathrm{R}_{\mathrm{f}}$ : 0.61 (petroleum ether-ethyl acetate 4:1). IR $\gamma_{\max }$ (Film) 3082, 2977, 2840, 1733, 1598, 1456, 1354. Anal. calcd for $\mathrm{C}_{16} \mathrm{H}_{16} \mathrm{~N}_{2} \mathrm{O}_{5}: \mathrm{C}, 60.76 ; \mathrm{H}, 5.10 ; \mathrm{N}, 8.86$; found: $\mathrm{C}, 60.84 ; \mathrm{H}, 5.19 ; \mathrm{N}, 8.75 .{ }^{1} \mathrm{H}-\mathrm{NMR}\left(\mathrm{CDCl}_{3}\right): \delta 1.36\left(\mathrm{t},{ }^{3} \mathrm{~J}_{\mathrm{H}-\mathrm{H}}=7.4 \mathrm{~Hz}, 3 \mathrm{H}, \mathrm{CH}_{2} \mathrm{CH}_{3}\right), 3.33(\mathrm{t}$, $\left.{ }^{3} J_{\mathrm{H}-\mathrm{H}}=7.4 \mathrm{~Hz}, 2 \mathrm{H}, \mathrm{CH}_{2} \mathrm{CH}_{3}\right), 3.72\left(\mathrm{~s}, 3 \mathrm{H}, \mathrm{OCH}_{3}\right), 3.98\left(\mathrm{~s}, 3 \mathrm{H}, \mathrm{COOCH}_{3}\right), 6.92\left(\mathrm{~d},{ }^{3} J_{\mathrm{H}-\mathrm{H}}=\overline{8.6} \mathrm{~Hz}, 1 \mathrm{H}\right.$, $\mathrm{CH}, \mathrm{Ar}), 7.13-7.18(\mathrm{~m}, 1 \mathrm{H}, \mathrm{CH}, \mathrm{Ar}), 7.43-7.50(\mathrm{~m}, 1 \mathrm{H}, \mathrm{CH}, \mathrm{Ar}), 7.76\left(\mathrm{dd},{ }^{3} J_{\mathrm{H}-\mathrm{H}}=7.6 \mathrm{~Hz},{ }^{3} J_{\mathrm{H}-\mathrm{H}}=1.7 \mathrm{~Hz}\right.$, $1 \mathrm{H}, \mathrm{CH}, \mathrm{Ar}), 8.70(\mathrm{~s}, 1 \mathrm{H}, \mathrm{C} 4 \mathrm{H})$. MS: $m / z=317[\mathrm{M}+1](100 \%)$.

\subsubsection{Methyl 2-methyl-5-nitro-6-(4-nitrophenyl)nicotinate (3f)}

White powder. Yield $0.088 \mathrm{~g}(93 \%)$. Mp $167-168^{\circ} \mathrm{C}$ (from ethanol). $\mathrm{R}_{\mathrm{f}}: 0.39$ (petroleum ether-ethyl acetate 4:1). IR $v_{\max }$ (Film) 3086, 2995, 1719, 1553, 1517, 1443, 1358, 1345. ${ }^{1} \mathrm{H}-\mathrm{NMR}\left(\mathrm{CDCl}_{3}\right): \delta 2.99$ (s, $\left.3 \mathrm{H}, \mathrm{CH}_{3}\right), 4.01\left(\mathrm{~s}, 3 \mathrm{H}, \mathrm{COOCH}_{3}\right), 7.73-7.75\left(\mathrm{dm},{ }^{3} J_{\mathrm{H}-\mathrm{H}}=9.1 \mathrm{~Hz}, 2 \mathrm{H}, 2 \times \mathrm{CH}, \mathrm{Ar}\right), 8.32-8.34\left(\mathrm{dm},{ }^{3} J_{\mathrm{H}-\mathrm{H}}\right.$ $=9.1 \mathrm{~Hz}, 2 \mathrm{H}, 2 \times \mathrm{CH}, \mathrm{Ar}), 8.80(\mathrm{~s}, 1 \mathrm{H}, \mathrm{C} 4 \mathrm{H}) .{ }^{13} \mathrm{C}-\mathrm{NMR}\left(\mathrm{CDCl}_{3}\right): \delta 25.4\left(\mathrm{~s}, \mathrm{CH}_{3}\right), 53.2\left(\mathrm{~s}, \mathrm{COOCH}_{3}\right), 124.0$ (s, 2×CH, Ar), 125.2 (s, $\left.\underline{\mathrm{C}}-\mathrm{COOCH}_{3}\right), 129.7$ (s, 2×CH, Ar), 135.5 (s, CH), $142.2\left(\mathrm{~s}, \mathrm{C}_{\mathrm{q}}, \mathrm{Ar}\right), 143.7$ (s, C5), 148.9 (s, C- $\left.\mathrm{NO}_{2}, \mathrm{Ar}\right), 152.5$ (s, C6), 164.2 (s, C2), 164.6 (s, C=O). HRMS (ESI ${ }^{+}$): Calcd for $\mathrm{C}_{14} \mathrm{H}_{11} \mathrm{~N}_{3} \mathrm{O}_{6}$ [M+ H]: 318.0726; found 318.0731.

\subsubsection{Methyl 6-(3-fluorophenyl)-2-methyl-5-nitronicotinate (3g)}

White powder. Yield $0.076 \mathrm{~g}(87 \%)$. Mp $105-107^{\circ} \mathrm{C}$ (from ethanol). $\mathrm{R}_{\mathrm{f}}: 0.61$ (petroleum ether-ethyl acetate 4:1). IR $v_{\max }$ (Film) 3094, 2963, 2848, 1726, 1595, 1533, 1515, 1442, 1304. ${ }^{1} \mathrm{H}-\mathrm{NMR}\left(\mathrm{CDCl}_{3}\right)$ : $\delta 2.98\left(\mathrm{~s}, 3 \mathrm{H}, \mathrm{CH}_{3}\right), 4.00\left(\mathrm{~s}, 3 \mathrm{H}, \mathrm{COOCH}_{3}\right), 7.20\left(\mathrm{tdd},{ }^{3} J_{\mathrm{H}-\mathrm{F}}=8.4 \mathrm{~Hz},{ }^{3} J_{\mathrm{H}-\mathrm{H}}=2.6 \mathrm{~Hz},{ }^{4} J_{\mathrm{H}-\mathrm{H}}=1.0 \mathrm{~Hz}\right.$, $1 \mathrm{H}, \mathrm{CH}, \mathrm{Ar}), 7.30-7.33\left(\mathrm{dm},{ }^{3} J_{\mathrm{H}-\mathrm{H}}=7.7 \mathrm{~Hz}, 1 \mathrm{H}, \mathrm{CH}, \mathrm{Ar}\right), 7.35-7.38\left(\mathrm{dm},{ }^{3} J_{\mathrm{H}-\mathrm{F}}=9.4 \mathrm{~Hz}, 1 \mathrm{H}, \mathrm{CH}, \mathrm{Ar}\right)$, $7.43\left(\mathrm{td},{ }^{3} J_{\mathrm{H}-\mathrm{H}}=8.0 \mathrm{~Hz},{ }^{4} J_{\mathrm{H}-\mathrm{H}}=5.6 \mathrm{~Hz}, 1 \mathrm{H}, \mathrm{CH}, \mathrm{Ar}\right), 8.71(\mathrm{~s}, 1 \mathrm{H}, \mathrm{C} 4 \mathrm{H}) ;{ }^{19} \mathrm{~F}-\mathrm{NMR}\left(\mathrm{CDCl}_{3}\right): \delta-111.8-$ $(-111.9)(\mathrm{m}, 1 \mathrm{~F}, \mathrm{CF}, \mathrm{Ar}) .{ }^{13} \mathrm{C}-\mathrm{NMR}\left(\mathrm{CDCl}_{3}\right): \delta 25.3\left(\mathrm{~s}, \mathrm{CH}_{3}\right), 53.1\left(\mathrm{~s}, \mathrm{COOCH}_{3}\right), 115.8\left(\mathrm{~d},{ }^{2} J_{\mathrm{C}-\mathrm{F}}=23.7 \mathrm{~Hz}\right.$, $\mathrm{CH}, \mathrm{Ar}), 117.5\left(\mathrm{~d},{ }^{2} J_{\mathrm{C}-\mathrm{F}}=21.5 \mathrm{~Hz}, \mathrm{CH}, \mathrm{Ar}\right), 124.1\left(\mathrm{~d},{ }^{4} J_{\mathrm{C}-\mathrm{F}}=3.1 \mathrm{~Hz}, \mathrm{CH}, \mathrm{Ar}\right), 124.4(\mathrm{~s}, \mathrm{C} 3), 130.5(\mathrm{~d}$, $\left.{ }^{3} J_{\mathrm{C}-\mathrm{F}}=8.1 \mathrm{~Hz}, \mathrm{CH}, \mathrm{Ar}\right), 135.2(\mathrm{~s}, \mathrm{C} 4 \mathrm{H}), 137.9\left(\mathrm{~s}, \mathrm{~d},{ }^{3} J_{\mathrm{C}-\mathrm{F}}=7.8 \mathrm{~Hz}, \mathrm{C}_{\mathrm{q}}, \mathrm{Ar}\right), 143.8(\mathrm{~s}, \mathrm{C} 5), 153.1\left(\mathrm{~d},{ }^{4} J_{\mathrm{C}-\mathrm{F}}=\right.$ $2.6 \mathrm{~Hz}, \mathrm{C} 6), 162.9\left(\mathrm{~d},{ }^{1} J_{\mathrm{C}-\mathrm{F}}=247.4 \mathrm{~Hz}, \mathrm{CF}, \mathrm{Ar}\right), 163.7(\mathrm{~s}, \mathrm{C} 2), 164.8(\mathrm{~s}, \mathrm{C}=\mathrm{O})$. HRMS (ESI ${ }^{+}$): Calcd for $\mathrm{C}_{14} \mathrm{H}_{11} \mathrm{FN}_{2} \mathrm{O}_{4}[\mathrm{M}+\mathrm{H}]: 291.0781$; found 291.0788. 


\subsubsection{Methyl 6-(1,3-diphenyl-1H-pyrazol-4-yl)-2-methyl-5-nitronicotinate (3h)}

Red yellow powder. Yield $0.098 \mathrm{~g}(79 \%) . \mathrm{Mp} 160-162{ }^{\circ} \mathrm{C}$ (from ethanol). $\mathrm{R}_{\mathrm{f}}$ : 0.41 (petroleum ether-ethyl acetate 4:1). ${ }^{1} \mathrm{H}-\mathrm{NMR}\left(\mathrm{CDCl}_{3}\right): \delta 2.95\left(\mathrm{~s}, 3 \mathrm{H}, \mathrm{CH}_{3}\right), 3.98\left(\mathrm{~s}, 3 \mathrm{H}, \mathrm{COOCH}_{3}\right), 7.32-7.40(\mathrm{~m}$, 6H, CH, Ph), 7.48-7.52 (m, 2H, CH, Ph), 7.82-7.85 (m, 2H, CH, Ph), 8.39 (s, 1H, CH, pyrazolyl), 8.67 (s, 1H, C4H); ${ }^{13} \mathrm{C}-\mathrm{NMR}\left(\mathrm{CDCl}_{3}\right): \delta 25.3\left(\mathrm{~s}, \mathrm{CH}_{3}\right), 53.0\left(\mathrm{~s}, \mathrm{COOCH}_{3}\right), 118.4\left(\mathrm{~s}, \mathrm{C}_{\mathrm{q}}\right.$, pyrazolyl), $119.6(\mathrm{~s}, \mathrm{Ph})$, 122.6 (s, C3), 127.3 (s, Ph), 127.9 (s, Ph), 128.7 (s, Ph), 128.8 (s, Ph), 129.4 (s, CH, pyrazolyl), 129.70 (s, Ph), 132.53 (s, C $\mathrm{q}, \mathrm{Ph}$ ), 135.5 (s, C4H), 139.7 (s, C, $\mathrm{Ph}), 143.3$ (s, C5), 148.3 (s, C6), 152.4 (s, C-Ph, pyrazolyl), 164.1 (s, C2), 164.9 (s, C=O). HRMS (ESI ${ }^{+}$): Calcd for $\mathrm{C}_{23} \mathrm{H}_{18} \mathrm{~N}_{4} \mathrm{O}_{4}[\mathrm{M}+\mathrm{H}]$ : 415.1406; found 415.1408.

\subsubsection{Diethyl 2,4-dimethyl-6-phenylpyridine-3,5-dicarboxylate (3k)}

Pale yellow oil. Yield $0.093 \mathrm{~g}(85 \%) . \quad \mathrm{R}_{\mathrm{f}}$ : 0.60 (petroleum ether-ethyl acetate 4:1). ${ }^{1} \mathrm{H}-\mathrm{NMR}$ $\left(\mathrm{CDCl}_{3}\right): \delta 0.99\left(\mathrm{t}^{3}{ }^{3} \mathrm{H}_{\mathrm{H}-\mathrm{H}}=7.1 \mathrm{~Hz}, 3 \mathrm{H}, \mathrm{COOCH}_{2} \mathrm{CH}_{3}\right), 1.42\left(\mathrm{t},{ }^{3} \mathrm{~J}_{\mathrm{H}-\mathrm{H}}=7.1 \mathrm{~Hz}, 3 \mathrm{H}, \mathrm{COOCH}_{2} \mathrm{CH}_{3}\right), 2.36$ $\left(\mathrm{s}, 3 \mathrm{H}, \mathrm{CH}_{3}\right), 2.61\left(\mathrm{~s}, 3 \mathrm{H}, \mathrm{CH}_{3}\right), 4.11\left(\mathrm{q},{ }^{3} J_{\mathrm{H}-\mathrm{H}}=\overline{7.1} \mathrm{~Hz}, 2 \mathrm{H}, \mathrm{COOCH}_{2} \mathrm{CH}_{3}\right), 4.45\left(\mathrm{q},{ }^{3} J_{\mathrm{H}-\mathrm{H}}=7.1 \mathrm{~Hz}\right.$, $\left.2 \mathrm{H}, \mathrm{COOCH}_{2} \mathrm{CH}_{3}\right), 7.40-7.42(\mathrm{~m}, 3 \mathrm{H}, 3 \times \mathrm{CH}, \mathrm{Ph}), 7.55-7.57(\mathrm{~m}, 2 \mathrm{H}, 2 \times \mathrm{CH}, \mathrm{Ph}) .{ }^{13} \mathrm{C}-\mathrm{NMR}\left(\mathrm{CDCl}_{3}\right)$ : $\delta 13.7\left(\mathrm{~s}, \mathrm{COOCH}_{2} \underline{\mathrm{CH}}_{3}\right), 14.4\left(\mathrm{~s}, \mathrm{COOCH}_{2} \mathrm{CH}_{3}\right), 17.0\left(\mathrm{~s}, \mathrm{CH}_{3}\right), 23.3\left(\mathrm{~s}, \mathrm{CH}_{3}\right), 61.7\left(\mathrm{~s}, \mathrm{COOCH}_{2} \mathrm{CH}_{3}\right)$, $61.9\left(\mathrm{~s}, \mathrm{COOCH}_{2} \mathrm{CH}_{3}\right), 127.4\left(\mathrm{~s}, \underline{\mathrm{C}}-\mathrm{COOCH}_{2} \mathrm{CH}_{3}\right), 128.4(\mathrm{~s}, 2 \times \mathrm{CH}, \mathrm{Ph}), 128.5(\mathrm{~s}, 2 \times \mathrm{CH}, \mathrm{Ph}), 128.6(\mathrm{~s}$, $\left.\underline{\mathrm{C}}-\mathrm{COOCH}_{2} \mathrm{CH}_{3}\right), 129.0(\mathrm{~s}, \mathrm{CH}, \mathrm{Ph}), 139.8(\mathrm{~s}, \mathrm{C}, \mathrm{Ph}), 143.0\left(\mathrm{~s}, \underline{\mathrm{C}}-\mathrm{CH}_{3}\right), 155.4(\mathrm{~s}, \mathrm{C} 6), 156.6\left(\mathrm{~s}, \underline{\mathrm{C}}-\mathrm{CH}_{3}\right)$, $168.50(\mathrm{~s}, \mathrm{C}=\mathrm{O}), 168.53$ (s, C=O); MS: $\mathrm{m} / \mathrm{z}=364[\mathrm{M}+1](100 \%)$. HRMS $\left(\mathrm{ESI}^{+}\right)$: Calcd for $\mathrm{C}_{19} \mathrm{H}_{19} \mathrm{~F}_{2} \mathrm{NO}_{4}$ $[\mathrm{M}+\mathrm{H}]: 364.1360$; found 364.1366 .

\subsection{General Procedure for the Synthesis of Methyl 2-(fluoromethyl)-5-nitro-6-arylnicotinates 5a-d}

Method A: To a stirred solution of 3-fluoro-5-nitro-3,6-dihydropyridines 2a,c,f,g (0.5 mmol) in dry acetonitrile $(5 \mathrm{~mL})$ in the presence of $3 \AA$ molecular sieves cooled to $0{ }^{\circ} \mathrm{C}$, a solution of Selectfluor ${ }^{\circledR}(0.340 \mathrm{~g}, 1 \mathrm{mmol})$ in dry acetonitrile $(10 \mathrm{~mL})$ was added in portions under an argon atmosphere. The reaction mixture was stirred for $10 \mathrm{~min}$ at $0{ }^{\circ} \mathrm{C}$, after which the temperature was slowly raised to room temperature. The reaction mixture was stirred for $48 \mathrm{~h}$ at room temperature under an argon atmosphere, then volatile compounds were evaporated in vacuo, diethyl ether $(15 \mathrm{~mL})$ was added to the residue and the precipitate was filtered. According to the LC-MS data, the filtrate contained a mixture of 2-(fluoromethyl)pyridines $\mathbf{5 a - d}$ and pyridines $\mathbf{3 a}, \mathbf{c}, \mathbf{f}, \mathbf{g}$. The filtrate was evaporated in vacuo and the residue was separated by column chromatography to give methyl 2-(fluoromethyl)-5-nitro-6-arylnicotinates $\mathbf{5 a - d}$ in 21-43\% yields and 2-methylpyridines $\mathbf{3 a , c , f}, \mathbf{g}$ in $10-52 \%$ yields.

Method B: To a stirred solution of 1,2-dihydropyridines $\mathbf{1 a , c , f}, \mathbf{f}, \mathbf{g}(0.5 \mathrm{mmol})$ in dry acetonitrile $(5 \mathrm{~mL})$ in the presence of $3 \AA$ molecular sieves cooled to $0^{\circ} \mathrm{C}$, a solution of Selectfluor ${ }^{\circledR}(0.53 \mathrm{~g}, 1.5 \mathrm{mmol})$ in dry acetonitrile $(10 \mathrm{~mL})$ was added dropwise under an argon atmosphere. The reaction mixture was stirred for $10 \mathrm{~min}$ at $0{ }^{\circ} \mathrm{C}$, after which the temperature was slowly raised to room temperature. The reaction mixture was stirred for $48 \mathrm{~h}$ at room temperature under an argon atmosphere. Then the reaction mixture was evaporated in vacuo, diluted with diethyl ether $(15 \mathrm{~mL})$ and the insoluble precipitate was filtered. The filtrate was evaporated in vacuo to give a mixture of 2-(fluoromethyl)pyridines $\mathbf{5 a - d}$ and pyridines $\mathbf{3 a}, \mathbf{c}, \mathbf{f}, \mathbf{g}$ in similar ratios as in Method A according to the ${ }^{1} \mathrm{H}-\mathrm{NMR}$ spectra and LC-MS data (Table 5).

Isolated yields for 2-(fluoromethyl)pyridines $\mathbf{5 a - d}$ and pyridines $\mathbf{3} \mathbf{a}, \mathbf{c}, \mathbf{f}, \mathbf{g}$ obtained by Method A are given.

\subsubsection{Methyl 2-(fluoromethyl)-5-nitro-6-phenylnicotinate (5a)}

Pale yellow oil. Yield $0.046 \mathrm{~g}(32 \%)$. $\mathrm{R}_{\mathrm{f}}: 0.45$ (petroleum ether-ethyl acetate 4:1). Anal. calcd for $\mathrm{C}_{14} \mathrm{H}_{11} \mathrm{FN}_{2} \mathrm{O}_{4}$ : C, 57.93; $\mathrm{H}, 3.82 ; \mathrm{N}, 9.65$; found: $\mathrm{C}, 58.06 ; \mathrm{H}, 3.93 ; \mathrm{N}, 9.52 .{ }^{1} \mathrm{H}-\mathrm{NMR}\left(\mathrm{CDCl}_{3}\right): \delta 4.02$ $\left(\mathrm{s}, 3 \mathrm{H}, \mathrm{COOCH}_{3}\right), 5.93\left(\mathrm{~d},{ }^{2} \mathrm{~J}_{\mathrm{H}-\mathrm{F}}=46.9 \mathrm{~Hz}, 2 \mathrm{H}, \mathrm{CH}_{2} \mathrm{~F}\right), 7.49-7.51(\mathrm{~m}, 3 \mathrm{H}, 3 \times \mathrm{CH}, \mathrm{Ph}), 7.65-6.67(\mathrm{~m}$, $2 \mathrm{H}, 2 \times \mathrm{CH}, \mathrm{Ph}), 8.71\left(\mathrm{~d},{ }^{5} J_{\mathrm{H}-\mathrm{F}}=1.1 \mathrm{~Hz}, 1 \mathrm{H}, \mathrm{C} 4 \mathrm{H}\right) .{ }^{19} \mathrm{~F}-\mathrm{NMR}\left(\mathrm{CDCl}_{3}\right): \delta-219.4\left(\mathrm{t},{ }^{2} J_{\mathrm{F}-\mathrm{H}}=46.9 \mathrm{~Hz}, 1 \mathrm{~F}\right.$, 
$\left.\mathrm{FCH}_{2}\right) .{ }^{13} \mathrm{C}-\mathrm{NMR}\left(\mathrm{CDCl}_{3}\right): \delta 53.4\left(\mathrm{~s}, \mathrm{COOCH}_{3}\right), 82.9\left(\mathrm{~d},{ }^{1} J_{\mathrm{C}-\mathrm{F}}=174.4 \mathrm{~Hz}, \mathrm{FCH}_{2}\right), 123.1\left(\mathrm{~s}, \underline{\mathrm{C}}-\mathrm{COOCH}_{3}\right)$, 128.7 (s, Ph), 129.1 (s, Ph), 131.0 (s, Ph), 135.15 (s, C , Ph), 135.20 (s, C4H), 144.9 (s, C5), 154.8 (s, C6), 159.2-156-4 (m, C2), 164.1 (s, C=O). MS: $m / z=291[\mathrm{M}+1](100 \%)$.

\subsubsection{Methyl 2-(fluoromethyl)-6-(2-methoxyphenyl)-5-nitronicotinate (5b)}

White powder. Yield $0.034 \mathrm{~g}(21 \%)$. Mp $143-145^{\circ} \mathrm{C}$ (from ethanol). $\mathrm{R}_{\mathrm{f}}: 0.38$ (petroleum ether-ethyl acetate 4:1). IR $v_{\max }$ (Film) 3095, 2953, 2924, 2848, 1736, 1595, 1562, 1521, 1494, 1466, 1437, 1351, 1304. Anal. calcd for $\mathrm{C}_{15} \mathrm{H}_{13} \mathrm{FN}_{2} \mathrm{O}_{5}$ : C, 56.25; $\mathrm{H}, 4.09 ; \mathrm{N}, 8.75$; found: $\mathrm{C}, 56.39 ; \mathrm{H}, 4.19 ; \mathrm{N}, 8.64 .{ }^{1} \mathrm{H}-\mathrm{NMR}$ $\left(\mathrm{CDCl}_{3}\right): \delta 3.72\left(\mathrm{~s}, 3 \mathrm{H}, \mathrm{OCH}_{3}\right), 4.01\left(\mathrm{~s}, 3 \mathrm{H}, \mathrm{COOCH}_{3}\right), 5.92\left(\mathrm{~d},{ }^{2} \mathrm{~J}_{\mathrm{H}-\mathrm{F}}=46.9 \mathrm{~Hz}, 2 \mathrm{H}, \mathrm{CH}_{2} \mathrm{~F}\right), 6.90-6.92(\mathrm{~m}$, $1 \mathrm{H}, \mathrm{CH}, \mathrm{Ar}), 7.15-7.19(\mathrm{~m}, 1 \mathrm{H}, \mathrm{CH}, \mathrm{Ar}), 7.46-7.50(\mathrm{~m}, 1 \mathrm{H}, \mathrm{CH}, \mathrm{Ar}), 7.80-7.82(\mathrm{~m}, 1 \mathrm{H}, \mathrm{CH}, \mathrm{Ar}), 8.77(\mathrm{~d}$, $\left.{ }^{5} J_{\mathrm{H}-\mathrm{F}}=1.1 \mathrm{~Hz}, 1 \mathrm{H}, \mathrm{C} 4 \mathrm{H}\right) \cdot{ }^{19} \mathrm{~F}-\mathrm{NMR}\left(\mathrm{CDCl}_{3}\right): \delta-219.1\left(\mathrm{t},{ }^{2} J_{\mathrm{F}-\mathrm{H}}=46.9 \mathrm{~Hz}, 1 \mathrm{~F}, \mathrm{FCH}_{2}\right) ;{ }^{13} \mathrm{C}-\mathrm{NMR}\left(\mathrm{CDCl}_{3}\right)$ : $53.3\left(\mathrm{~s}, \mathrm{COOCH}_{3}\right), 55.10\left(\mathrm{~s}, \mathrm{OCH}_{3}\right), 82.9\left(\mathrm{~d},{ }^{1} \mathrm{~J}_{\mathrm{C}-\mathrm{F}}=173.91 \mathrm{~Hz}, \mathrm{FCH}_{2}\right), 110.8(\mathrm{~s}, \mathrm{CH}, \mathrm{Ar}), 121.8(\mathrm{~s}, \mathrm{CH}$, $\mathrm{Ar}), 123.1$ (s, C3), 125.3 (s, C, $\mathrm{Ar}), 131.4$ (s, CH, Ar), 131.5 (s, CH, Ar), 134.6 (s, C4H), 145.9 (s, C5), $152.6(\mathrm{~s}, \mathrm{C} 6), 156.7(\mathrm{~s}, \underline{\mathrm{C}}-\mathrm{OMe}, \mathrm{Ar}), 159.2\left(\mathrm{~d},{ }^{2} J_{\mathrm{C}-\mathrm{F}}=15.4 \mathrm{~Hz}, \mathrm{C} 2\right), 164.3(\mathrm{~s}, \mathrm{C}=\mathrm{O}) . \mathrm{MS}: \mathrm{m} / z=321[\mathrm{M}+1]$ $(100 \%)$.

\subsubsection{Methyl 2-(fluoromethyl)-5-nitro-6-(4-nitrophenyl)nicotinate (5c)}

White powder. Yield $0.049 \mathrm{~g}(38 \%) . \mathrm{Mp} 150-151^{\circ} \mathrm{C}$ (from ethanol). $\mathrm{R}_{\mathrm{f}}: 0.43$ (petroleum ether-ethyl acetate 4:1). IR $v_{\max }$ (Film) 3101, 2958, 2860, 1728, 1596, 1555, 1522, 1437, 1351, 1300. ${ }^{1} \mathrm{H}-\mathrm{NMR}\left(\mathrm{CDCl}_{3}\right)$ : $\delta 4.04\left(\mathrm{~s}, 3 \mathrm{H}, \mathrm{COOCH}_{3}\right), 5.94\left(\mathrm{~d},{ }^{2} J_{\mathrm{H}-\mathrm{F}}=46.6 \mathrm{~Hz}, 2 \mathrm{H}, \mathrm{CH}_{2} \mathrm{~F}\right), 7.79-7.82(\mathrm{~m}, 2 \mathrm{H}, 2 \times \mathrm{CH}, \mathrm{Ar}), 8.33-8.37$ $(\mathrm{m}, 2 \mathrm{H}, 2 \times \mathrm{CH}, \mathrm{Ar}), 8.83\left(\mathrm{~d},{ }^{5} J_{\mathrm{H}-\mathrm{F}}=1.1 \mathrm{~Hz}, 1 \mathrm{H}, \mathrm{CH}\right) .{ }^{19} \mathrm{~F}-\mathrm{NMR}\left(\mathrm{CDCl}_{3}\right): \delta-220.1\left(\mathrm{t},{ }^{2} J_{\mathrm{F}-\mathrm{H}}=46.6 \mathrm{~Hz}, 1 \mathrm{~F}\right.$, $\left.\mathrm{FCH}_{2}\right) .{ }^{13} \mathrm{C}-\mathrm{NMR}\left(\mathrm{CDCl}_{3}\right): \delta 53.6\left(\mathrm{~s}, \mathrm{COOCH}_{3}\right), 82.6\left(\mathrm{~d},{ }^{1} J_{\mathrm{C}-\mathrm{F}}=175.8 \mathrm{~Hz}, \mathrm{FCH}_{2}\right), 124.1(\mathrm{~s}, 2 \times \mathrm{CH}, \mathrm{Ar})$, 124.6 (s, C3), 129.9 (s, 2×CH, Ar), $135.6(\mathrm{~s}, \mathrm{C} 4 \mathrm{H}), 141.4$ (s, C5), 145.0 (s, C $\mathrm{q}, \mathrm{Ar}), 149.1$ (s, C-NO $\left.\mathrm{NO}_{2}, \mathrm{Ar}\right)$, $152.8(\mathrm{~s}, \mathrm{C} 6), 159.8\left(\mathrm{~d},{ }^{2} J_{\mathrm{C}-\mathrm{F}}=15.0 \mathrm{~Hz}, \mathrm{C} 2\right), 163.6(\mathrm{~s}, \mathrm{C}=\mathrm{O}) ; \mathrm{MS}: \mathrm{m} / \mathrm{z}=336[\mathrm{M}+1](100 \%)$. HRMS $\left(\mathrm{ESI}^{+}\right)$: Calcd for $\mathrm{C}_{14} \mathrm{H}_{10} \mathrm{FN}_{3} \mathrm{O}_{6}[\mathrm{M}+\mathrm{H}]$ : 336.0632; found 336.0634.

\subsubsection{Methyl 2-(fluoromethyl)-6-(3-fluorophenyl)-5-nitronicotinate (5d)}

White powder. Yield $0.057 \mathrm{~g}$, (43\%). Mp 107-109 ${ }^{\circ} \mathrm{C}$ (from ethanol). $\mathrm{R}_{\mathrm{f}}$ : 0.42 (petroleum ether-ethyl acetate 4:1). IR $v_{\max }$ (Film) 3098, 2976, 2919, 2861, 1714, 1597, 1557, 1519, 1436, 1351, 1309. ${ }^{1} \mathrm{H}-\mathrm{NMR}\left(\mathrm{CDCl}_{3}\right): \delta 4.02\left(\mathrm{~s}, 3 \mathrm{H}, \mathrm{COOCH}_{3}\right), 5.93\left(\mathrm{~d},{ }^{2} \mathrm{~J}_{\mathrm{H}-\mathrm{F}}=46.6 \mathrm{~Hz}, 2 \mathrm{H}, \mathrm{CH}_{2} \mathrm{~F}\right), 7.20-7.25$ (m, 1H, CH, Ar), 7.36-7.48 (m, 3H, 3×CH, Ar), $8.73\left(\mathrm{~d},{ }^{5} J_{\mathrm{H}-\mathrm{F}}=0.6 \mathrm{~Hz}, 1 \mathrm{H}, \mathrm{CH}\right) .{ }^{19} \mathrm{~F}-\mathrm{NMR}\left(\mathrm{CDCl}_{3}\right)$ : $\delta-111.45-1111.51(\mathrm{~m}, 1 \mathrm{~F}, \mathrm{CF}, \mathrm{Ar}),-219.6\left(\mathrm{t},{ }^{2} J_{\mathrm{F}-\mathrm{H}}=46.6 \mathrm{~Hz}, 1 \mathrm{~F}, \mathrm{FCH}_{2}\right) .{ }^{13} \mathrm{C}-\mathrm{NMR}\left(\mathrm{CDCl}_{3}\right): \delta 54.5(\mathrm{~s}$, $\left.\mathrm{COOCH}_{3}\right), 82.7\left(\mathrm{~d},{ }^{1} J_{\mathrm{C}-\mathrm{F}}=174.7 \mathrm{~Hz}, \mathrm{FCH}_{2}\right), 116.0\left(\mathrm{~d},{ }^{2} J_{\mathrm{C}-\mathrm{F}}=23.5 \mathrm{~Hz}, \mathrm{CH}, \mathrm{Ar}\right), 118.0\left(\mathrm{~d},{ }^{2} J_{\mathrm{C}-\mathrm{F}}=20.9 \mathrm{~Hz}\right.$, $\mathrm{CH}, \mathrm{Ar}), 123.8(\mathrm{~s}, \mathrm{CH}, \mathrm{Ar}), 124.3\left(\mathrm{~d},{ }^{3} \mathrm{~J}_{\mathrm{C}-\mathrm{F}}=3.2 \mathrm{~Hz}, \mathrm{C} 3\right), 130.7\left(\mathrm{~d},{ }^{3} J_{\mathrm{C}-\mathrm{F}}=8.2 \mathrm{~Hz}, \mathrm{CH}, \mathrm{Ar}\right), 135.3(\mathrm{~s}, \mathrm{CH})$, $137.2\left(\mathrm{~d},{ }^{3} J_{\mathrm{C}-\mathrm{F}}=7.1 \mathrm{~Hz}, \mathrm{C}_{\mathrm{q}}, \mathrm{Ar}\right), 145.0(\mathrm{~s}, \mathrm{C} 5), 153.4\left(\mathrm{~d},{ }^{4} \mathrm{~J}_{\mathrm{C}-\mathrm{F}}=3.1 \mathrm{~Hz}, \mathrm{C} 6\right), 159.3\left(\mathrm{~d},{ }^{2} J_{\mathrm{C}-\mathrm{F}}=15.9 \mathrm{~Hz}, \mathrm{C} 2\right)$, $163.0\left(\mathrm{~d},{ }^{1} J_{\mathrm{C}-\mathrm{F}}=247.4 \mathrm{~Hz}, \mathrm{CF}, \mathrm{Ar}\right), 163.9(\mathrm{~s}, \mathrm{C}=\mathrm{O}) . \mathrm{MS}: \mathrm{m} / z=309[\mathrm{M}+1](100 \%)$. HRMS (ESI $\left.{ }^{+}\right)$: Calcd for $\mathrm{C}_{14} \mathrm{H}_{10} \mathrm{~F}_{2} \mathrm{~N}_{2} \mathrm{O}_{4}[\mathrm{M}+\mathrm{H}]$ : 309.0687; found 309.0692 .

\section{Conclusions}

A series of new fluorinated 3,6-dihydropyridines $2 \mathbf{a}-\mathbf{k}$ can be obtained by the reaction of 1,2-dihydropyridines $\mathbf{1 a}-\mathbf{k}$ with Selectfluor ${ }^{\circledR}$. According to quantum chemical calculations, the 3,6-dihydropyridine ring of 3-fluoro-3,6-dihydropyridines $2 \mathbf{a}-\mathbf{k}$ was shown to be planar or near planar. The large values of the long-range ${ }^{5} J\left({ }^{1} \mathrm{H}_{,}{ }^{19} \mathrm{~F}\right)$ coupling constants registered in the ${ }^{1} \mathrm{H}$ and ${ }^{19} \mathrm{~F}-\mathrm{NMR}$ spectra of compounds 2 were apparently due to the homoallyl long-range coupling transmitted through $\pi$-electrons across a double bond of the heterocycle rather than by through-space interaction. The elimination of hydrogen fluoride under mild conditions can easily convert 3-Fluoro-3,6-dihydropyridines $\mathbf{2 a}-\mathbf{k}$ to corresponding pyridines $\mathbf{3} \mathbf{a}-\mathbf{k}$. A new approach to the synthesis of methyl 2-(fluoromethyl)-5-nitro-6-arylnicotinates $\mathbf{5 a - d}$ by the reaction of 3-fluoro-2-methyl-5-nitro-3,6-dihydropyridines $\mathbf{2 a , c , f}, \mathbf{g}$ or 1,2-dihydropyridines $\mathbf{1 a , c , f}, \mathbf{g}$ with Selectfluor ${ }^{\circledR}$ has been also proposed. 
Supplementary Materials: The following are available online: one-dimensional ${ }^{1} \mathrm{H},{ }^{19} \mathrm{~F},{ }^{13} \mathrm{C}$ and two-dimensional $\left\{{ }^{1} \mathrm{H}-{ }^{1} \mathrm{H}\right\}$ COSY, $\left\{{ }^{13} \mathrm{C}-{ }^{1} \mathrm{H}\right\}$ HSQC, $\left\{{ }^{13} \mathrm{C}-{ }^{1} \mathrm{H}\right\}$ HMBC-NMR spectral data of compounds $\mathbf{2 a}-\mathbf{k}, \mathbf{3 a}-\mathbf{k}$ and $5 \mathbf{a}-\mathbf{d}$ (file type pdf), the optimised structures of compounds $\mathbf{2} \mathbf{a}-\mathbf{k}$ are provided in Gaussian output files.

Author Contributions: N.V.P., Y.G.S. and A.S. conceived and designed the experiments; N.V.P., B.V., M.R., and A.P. performed the experiments; N.V.P., K.P., M.P., R.M. analysed the data; K.P., and A.S. contributed reagents/materials/analysis tools; and N.V.P., and Y.G.S. wrote the paper. All authors have read and agreed to the published version of the manuscript.

Funding: This research was supported by the PostDoc project Nr.1.1.1.2/VIAA/2/18/373 of N. Pikun entitled as "Electrophilic fluorination as an effective tool for the synthesis of new bioactive molecules and studies of fluorine substitution effects on the physicochemical properties of obtained compounds".

Conflicts of Interest: The authors declare no conflict of interest.

\section{References}

1. Petrov, V.A. Fluorinated Heterocyclic Compounds: Synthesis, Chemistry, and Applications; Wiley: Hoboken, NJ, USA, 2009; pp. 1-432. ISBN 9780470452110.

2. Gakh, A.A.; Kirk, K.L. Fluorinated Heterocycles. In ACS Symposium Series; American Chemical Society: Washington, DC, USA, 2009; Volume 1003, pp. 3-20. ISBN 9780841269538.

3. Nenajdenko, V. Fluorine in heterocyclic chemistry: Volume 2: 6-Membered heterocycles. In Fluorine in Heterocyclic Chemistry: Volume 2: 6-Membered Heterocycles; Springer International Publishing: Berlin, Germany, 2014; pp. 1-760. ISBN 9783319044354.

4. Wang, J.; Scott, A.I. Fluoro-decarboxylation of pyrrolecarboxylic acids by F-TEDA-BF 4 - A convenient general synthesis of fluoropyrroles. J. Chem. Soc. Chem. Commun. 1995, 23, 2399-2400. [CrossRef]

5. Hiramatsu, K.; Tamamura, H. A Mild Method for the Direct Fluorination of Pyrroles by Using a Lipophilic Anionic Phase-Transfer Catalyst. European J. Org. Chem. 2016, 2016, 3491-3494. [CrossRef]

6. Forrest, A.K.; O'Hanlon, P.J. The preparation and lithiation of bromofluorofurans via a novel fluorodecarboxylation. Tetrahedron Lett. 1995, 36, 2117-2118. [CrossRef]

7. Kobarfard, F.; Kauffman, J.M.; Boyko, W.J. Attempted syntheses of aminofluorothiophenes. J. Heterocycl. Chem. 1999, 36, 1247-1251. [CrossRef]

8. Wang, X.; Seth, P.P.; Ranken, R.; Swayze, E.E.; Migawa, M.T. Synthesis and Biological Activity of 5-Fluorotubercidin. Nucleosides Nucleotides Nucleic Acids 2004, 23, 161-170. [CrossRef]

9. Thiyagarajan, A.; Salim, M.T.A.; Balaraju, T.; Bal, C.; Baba, M.; Sharon, A. Structure based medicinal chemistry approach to develop 4-methyl-7-deazaadenine carbocyclic nucleosides as anti-HCV agent. Bioorganic Med. Chem. Lett. 2012, 22, 7742-7747. [CrossRef]

10. O'Neill, P.M.; Storr, R.C.; Park, B.K. Synthesis of the 8-aminoquinoline antimalarial 5-fluoroprimaquine. Tetrahedron 1998, 54, 4615-4622. [CrossRef]

11. Tang, P.; Ritter, T. Silver-mediated fluorination of aryl silanes. Tetrahedron 2011, 67, 4449-4454. [CrossRef]

12. Gu, Q.; Vessally, E. N-Fluorobenzenesulfonimide: A useful and versatile reagent for the direct fluorination and amination of (hetero)aromatic C-H bonds. RSC Adv. 2020, 10, 16756-16768. [CrossRef]

13. Takeuchi, Y.; Tarui, T.; Shibata, N. A novel and efficient synthesis of 3-fluorooxindoles from indoles mediated by Selectfluor. Org. Lett. 2000, 2, 639-642. [CrossRef]

14. Bisht, G.S.; Gnanaprakasam, B. Transition-metal-free addition reaction for the synthesis of 3-(aminobenzylidene/aminoalkylidene)indolin-2-ones and its synthetic applications. J. Org. Chem. 2019, 84, 13516-13527. [CrossRef] [PubMed]

15. Shibata, N.; Tarui, T.; Doi, Y.; Kirk, K.L. Synthesis of fluorogypsetin and fluorobrevianamide E by a novel fluorination - Cyclization of cyclo-L-Trp-L-AAs. Angew. Chemie Int. Ed. 2001, 40, 4461-4463. [CrossRef]

16. Yuan, X.; Yao, J.F.; Tang, Z.Y. Decarboxylative Fluorination of Electron-Rich Heteroaromatic Carboxylic Acids with Selectfluor. Org. Lett. 2017, 19, 1410-1413. [CrossRef] [PubMed]

17. Hodson, H.F.; Madge, D.J.; Slawin, A.N.Z.; Widdowson, D.A.; Williams, D.J. Electrophilic fluorination in the synthesis of new fluoroindoles. Tetrahedron 1994, 50, 1899-1906. [CrossRef]

18. Jiang, X.; Wang, H.; He, H.; Wang, W.; Wang, Y.; Ke, Z.; Yeung, Y.-Y. Enantioseletive Fluorination of 3-Functionalized Oxindoles Using Electron-rich Amino Urea Catalyst. Adv. Synth. Catal. 2018, 360, 4710-4714. [CrossRef] 
19. Baudoux, J.; Salit, A.; Cahard, D.; Plaquevent, J.C. Ionic liquids as solvents of choice for electrophilic fluorination: Fluorination of indoles by F-TEDA-BF 4 . Tetrahedron Lett. 2002, 43, 6573-6574. [CrossRef]

20. Yang, Q.; Dai, G.L.; Yang, Y.M.; Luo, Z.; Tang, Z.Y. Solvent Effects: Syntheses of 3,3-Difluorooxindoles and 3-Fluorooxindoles from Hydrazonoindolin-2-one by Selectfluor. J. Org. Chem. 2018, 83, 6762-6768. [CrossRef]

21. Li, J.; Cai, Y.; Chen, W.; Liu, X.; Lin, L.; Feng, X. Highly enantioselective fluorination of unprotected 3-substituted oxindoles: One-step synthesis of BMS 204352 (MaxiPost). J. Org. Chem. 2012, 77, 9148-9155. [CrossRef] [PubMed]

22. Shibata, N.; Suzuki, E.; Asahi, T.; Shiro, M. Enantioselective fluorination mediated by cinchona alkaloid derivatives/Selectfluor combinations: Reaction scope and structural information for $N$-fluorocinchona alkaloids. J. Am. Chem. Soc. 2001, 123, 7001-7009. [CrossRef]

23. Abramovitch, R.A. The Chemistry of Heterocyclic Compounds, 14, Parts 1-4, Supplement: Pyridine and Its Derivatives. In The Chemistry of Heterocyclic Compounds; John Wiley \& Sons: Hoboken, NJ, USA, 2007; ISBN 9780470188132.

24. Van Der Puy, M. Direct fluorination of substituted pyridines. Tetrahedron Lett. 1987, 28, 255-258. [CrossRef]

25. Anders, E.; Opitz, A.; Bauer, W. Remote Controlled Nucleophilicity, 21: Lithiated C $\alpha$-Substituted 4-Methylpyridines. Synthesis (Stuttg) 1991, 1991, 1221-1227. [CrossRef]

26. Ying, W.; DesMarteau, D.D.; Gotoh, Y. N-fluoro-bis[(trifluoromethyl)sulfonyl]imide: Electrophilic fluorination of imines and some methyl-substituted pyridines. Tetrahedron 1996, 52, 15-22. [CrossRef]

27. Baudoux, J.; Cahard, D. Electrophilic Fluorination with N-F Reagents. In Organic Reactions; John Wiley \& Sons, Inc.: Hoboken, NJ, USA, 2008; pp. 1-326.

28. Moberg, C.; Adolfsson, H.; Wärnmark, K.; Norrby, P.-O.; Marstokk, K.-M.; Møllendal, H. Conformational Preference of 2-(Halomethyl)- and 2-(Oxymethyl)Pyridines: Microwave Spectrum, Ab Initio, and MM3 Studies of 2-(Fluoromethyl)Pyridine. Chem. A Eur. J. 1996, 2, 516-522. [CrossRef]

29. Andrews, S.P.; Brown, G.A.; Congreve, M.S.; Mason, J.S.; Richardson, C.M. 1,2,4-Triazine-4-amine derivatives. PCT Int. Appl. WO2011095625 A, 2011.

30. Pikun, N.V.; Kolesnyk, N.V.P.; Rusanov, E.B.; Plotniece, A.; Rucins, M.; Sobolev, A.; Shermolovich, Y.G. Synthesis of fluorinated 2,6-heptanediones and 2-oxa-6-azabicyclo[2.2.2]octanes from 1,4-dihydropyridines. Tetrahedron 2018, 74, 2884-2890. [CrossRef]

31. Pikun, N.V.; Kolesnyk, N.V.P.; Rusanov, E.B.; Plotniece, A.; Sobolev, A.; Domracheva, I.; Shermolovich, Y.G. Contrasting reactivity of fluorinated 2,6-heptanediones towards amines and ammonia, leading to cyclohexanediones or 2-oxa-6-azabicyclo[2.2.2]octanes and evaluation of their cytotoxicity. New J. Chem. 2019, 43, 10537-10544. [CrossRef]

32. Ananthakrishnan, R.; Gazi, S. [Ru(bpy)3]2+ aided photocatalytic synthesis of 2-arylpyridines via Hantzsch reaction under visible irradiation and oxygen atmosphere. Catal. Sci. Technol. 2012, 2, 1463-1471. [CrossRef]

33. Eisner, U.; Sadeghi, M.M. Isomerisation of dihydropyridines. Tetrahedron Lett. 1978, 19, 299-302. [CrossRef]

34. Reine, I.; Muceniece, D.; Lusis, V.; Kemme, A. 2-Azabicyclo[2.2.2]oct-7-enes. 1. Synthesis from polysubstituted 1,2-dihydropyridines. Heterocycl. Commun. 2002, 8, 173-178. [CrossRef]

35. Ondrus, T.A.; Knaus, E.E.; Ciam, C.S. Some reactions of 1,2-dihydropyridines with cyanogen azide. Synthesis of üiazabieyclo[4.1.0]hept-4-enes. J. Heterocycl. Chem. 1979, 16, 409-410. [CrossRef]

36. Xu, Y.; Wang, Y.; Zhu, S.; Zhu, G.; Jia, Y.; Huang, Q. Synthesis of N-(1,2,3,6-tetrahydropyridylidene)fluoroalkanesulfonylamides from reactions of per(poly)fluoroalkanesulfonyl azides with 1,2-dihydropyridines. J. Fluor. Chem. 2000, 106, 133-138. [CrossRef]

37. Francis, R.F.; Crews, C.D.; Scott, B.S. Identification of 2,5-Dihydropyridine Intermediates in the Reactions of 2-Alkyl(Phenyl)-1-lithio-1,2-dihydropyridines with Alkyl Halides. J. Org. Chem. 1978, 43, 3227-3230. [CrossRef]

38. Giam, C.S.; Knaus, E.E.; Pasutto, F.M. Carbon vs. Nitrogen Acylation in Reactions of Organolithium-Pyridine Adducts with Acid Chlorides and Esters. J. Org. Chem. 1974, 39, 3565-3568. [CrossRef]

39. Giam, C.S.; Knaus, E.E.; Lockhart, R.A.; Keener, I.G. Some Reactions of 1-Lithio-2-phenyl-1,2-dihydropyridine. IV. Synthesis of $\beta$-Substituted Pyridines. Can. J. Chem. 1975, 53, 2305-2310. [CrossRef]

40. Ondrus, T.A.; Pasutto, F.M.; Knaus, E.E.; Giam, C.S. Some reactions of 2- $n$-butyl(phenyl)-1,2-dihydropyridines with isocyanates, pyridyl esters, and diethyl chlorophosphate. Can. J. Chem. 1978, 56, 1913-1918. [CrossRef] 
41. Vigante, B.; Plotniece, A.; Rucins, M.; Petrova, M.; Muhamadejev, R.; Pajuste, K.; Belyakov, S.; Shermolovich, Y.G.; Sobolev, A. An efficient synthesis of multisubstituted 4-nitrobuta-1,3-dien-1-amines and application in cyclisation reactions. Tetrahedron 2018, 74, 2596-2607. [CrossRef]

42. Hennig, M.; Munzarová, M.L.; Bermel, W.; Scott, L.G.; Sklenář, V.; Williamson, J.R. Measurement of long-range 1H-19F scalar coupling constants and their glycosidic torsion dependence in 5-fluoropyrimidine- substituted RNA. J. Am. Chem. Soc. 2006, 128, 5851-5858. [CrossRef]

43. Hilton, J.; Sutcliffe, L.H. The "through-space" mechanism in spin spin coupling. Prog. Nucl. Magn. Reson. Spectrosc. 1975, 10, 27-39. [CrossRef]

44. Myhre, P.C.; Edmonds, J.W.; Kruger, J.D. Long-Range Spin-Spin Coupling in Alkylfluorobenzenes. The Stereochemical Requirements for Coupling of Fluorine and Hydrogen Separated by Five Bonds. J. Am. Chem. Soc. 1966, 88, 2459-2466. [CrossRef]

45. Abraham, R.J.; Mobli, M. Modelling H-NMR Spectra of Organic Compounds: Theory, Applications and NMR Prediction Software. In Modelling H-NMR Spectra of Organic Compounds: Theory, Applications and NMR Prediction Software; John Wiley \& Sons: Hoboken, NJ, USA, 2008; pp. 1-380. ISBN 9780470723012.

46. Grossel, M.C.; Cheetham, A.K.; Newsam, J.M. The effect of bulky substituents on the conformation of cyclohexa-1,4-diene. Tetrahedron Lett. 1978, 19, 5229-5232. [CrossRef]

47. Atkinson, D.J.; Perkins, M.J. A comment on the magnitude of homoallylic coupling and the conformation of 1,4-cyclohexadiene. Tetrahedron Lett. 1969, 10, 2335-2338. [CrossRef]

48. Grossel, M.C.; Cheetham, A.K.; Hope, D.A.O.; Lam, K.P.; Perkins, M.J. The preferred conformation of cis-1,4-dihydro-4-tritylbiphenyl: A flexible cyclohexa-1,4-diene. Tetrahedron Lett. 1979, 20, 1351-1354. [CrossRef]

49. Cheetham, A.K.; Newsam, J.M.; Grossel, M.C. Conformational Studies of Dihydrotetraphenylmethanes. 1. X-ray Crystallographic and Solution ${ }^{1} \mathrm{H}-\mathrm{NMR}$ Studies of trans-1,4-Dihydro-4-tritylbiphenyl and Its 4'-Bromo Derivative: Boat-Boat Inversion in a Congested Cyclohexa-1,4-diene. J. Am. Chem. Soc. 1981, 103, 5363-5372. [CrossRef]

50. Garbisch, E.W.; Griffith, M.G. The Conformation of 1,4-Cyclohexadiene from Stereoisomeric Allylic-Allylic Proton Couplings. J. Am. Chem. Soc. 1968, 90, 3590-3592. [CrossRef]

51. Frisch, M.J.; Trucks, G.W.; Schlegel, H.B.; Scuseria, G.E.; Robb, M.A.; Cheeseman, J.R.; Scalmani, G.; Barone, V.; Mennucci, B.; Petersson, G.A.; et al. Gaussian 09; revision D.01; Gaussian, Inc.: Wallingford, CT, USA, 2013.

52. Grimme, S.; Antony, J.; Ehrlich, S.; Krieg, H. A consistent and accurate ab initio parametrization of density functional dispersion correction (DFT-D) for the 94 elements H-Pu. J. Chem. Phys. 2010, 132. [CrossRef]

Sample Availability: Samples of the compounds $\mathbf{3 a , c , e}$ and $\mathbf{5 a , d}$ are available from the authors.

(C) 2020 by the authors. Licensee MDPI, Basel, Switzerland. This article is an open access article distributed under the terms and conditions of the Creative Commons Attribution (CC BY) license (http://creativecommons.org/licenses/by/4.0/). 